
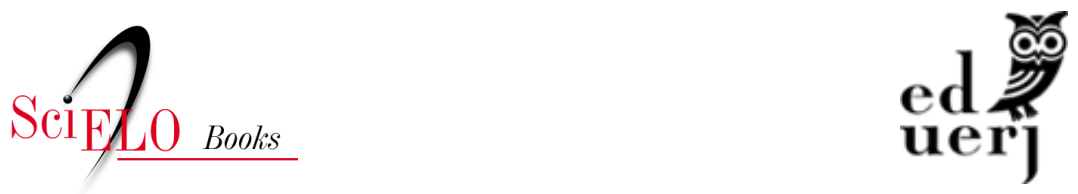

\title{
1. Sistema interestatal capitalista, política externa e autonomia
}

\author{
Tiago Nery
}

\section{SciELO Books / SciELO Livros / SciELO Libros}

NERY, T. Sistema interestatal capitalista, política externa e autonomia. In: A política externa brasileira e a UNASUL: geopolítica e expansão do capitalismo brasileiro na América do Sul [online]. Rio de Janeiro: EDUERJ, 2021, pp. 37-107. Sociedade e política collection. ISBN: 978-65-87949-19-2.

https://doi.org/10.7476/9786587949192.0003.

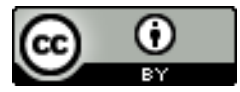

All the contents of this work, except where otherwise noted, is licensed under a Creative Commons Attribution 4.0 International license.

Todo o conteúdo deste trabalho, exceto quando houver ressalva, é publicado sob a licença Creative Commons Atribição 4.0.

Todo el contenido de esta obra, excepto donde se indique lo contrario, está bajo licencia de la licencia Creative Commons Reconocimento 4.0. 


\section{Sistema interestatal capitalista, POlítica EXTERNA E AUTONOMIA}

Este capítulo trata das relações entre política externa, sistema econômico internacional e autonomia. Na primeira seção, são analisadas as dimensões sistêmica e doméstica da política externa. A partir da crítica ao neorrealismo e à sua visão unitária do Estado como ator racional, procura-se analisar as inter-relações entre as variáveis estruturais e os múltiplos determinantes internos dos Estados. Para isso, são utilizadas abordagens teóricas, como a análise de política externa e a teoria da política burocrática, responsáveis por um esforço de integração entre os níveis doméstico e internacional. Destaca-se a importância das burocracias e das coalizões políticas nos processos de formulação e implementação da política externa, assumida como uma política pública sujeita aos jogos estratégicos entre atores em luta pelo poder. Apesar de características que apontam para uma política de Estado, como o peso da burocracia e o caráter incremental das mudanças, a política externa brasileira é também uma política pública e sofre mudanças que afetam sua agenda e seus atores, tanto por motivos sistêmicos quanto por razões internas.

A segunda seção traça um panorama histórico das relações entre Estado e capitalismo, poder e dinheiro. Analisa-se o surgimento do novo modo de produção na Europa, responsável pela criação simultânea de um sistema interestatal e de um sistema transacional, a partir do qual se formou o mercado global. Para analisar a relação entre a acumulação de capital e a expansão do poder do Estado, utilizam-se abordagens de alguns teóricos do imperialismo 
e do sistema-mundo. Essa relação ocorre por meio da fusão de duas lógicas opostas, ainda que entrelaçadas, de poder: a lógica capitalista e a lógica territorial. Embora não seja o único ator num mundo com elevado grau de complexificação, o Estado continua sendo a entidade política mais capacitada para combinar essas duas lógicas. De modo sintético, a seção analisa as principais contribuições da CEPAL, com destaque para o conceito de centro-periferia e a dinâmica do capitalismo nos países periféricos. Destaca-se, ainda, a tensão permanente entre capitalismo e sistema interestatal.

A terceira seção trata da atual ordem econômica internacional e de sua geografia do poder, cuja compreensão requer uma análise da especificidade da hegemonia exercida pelos Estados Unidos, a qual tem sua origem na expansão da sociedade de mercado e do regime de acumulação fordista. A ordem mundial pós-1945, baseada nos acordos de Bretton Woods, procurou generalizar nos países desenvolvidos o contrato social do consumo de massas, o keynesianismo e o planejamento econômico. No entanto, o embedded liberalism e as instituições nunca se generalizaram para os países periféricos. De maneira sucinta, observam-se as peculiaridades da industrialização periférica e o papel do Estado e do capital estrangeiro nesse processo. São analisados, ainda, o novo regime de acumulação, o fim de Bretton Woods e as reformas pró-mercado que se difundiram nas décadas de 1980 e 1990, destacando-se seu impacto nos países da periferia. Além disso, destaca-se a ascensão da China e do BRICS, que poderão contribuir para tornar a ordem internacional mais híbrida e menos liberal, apesar de os Estados Unidos continuarem exercendo enorme influência econômica, política e militar.

$\mathrm{Na}$ quarta seção, discute-se o conceito de autonomia, que tem sido objeto do campo de análise da política externa na América Latina. Analisa-se brevemente a criação da Unasul, vertente política da integração regional. O novo organismo, que surgiu após a ascensão de partidos progressistas, projeta geopoliticamente a América do Sul e contribui para a inserção autônoma da região no 
sistema internacional, sobretudo frente aos Estados Unidos. Por fim, chama-se a atenção para o processo de internacionalização das empresas brasileiras no subcontinente, que tem tornado conflituosa as relações entre a dimensão política e econômica do projeto de integração centrado na Unasul. Essa tensão gera enormes desafios tanto para a política externa brasileira quanto para o futuro da integração sul-americana. $\mathrm{O}$ capítulo se encerra com uma breve síntese das principais temáticas tratadas ao longo das seções.

\subsection{As dimensões sistêmica e doméstica da política externa}

As relações internacionais e a política doméstica encontram-se, de alguma forma, emaranhadas. Apesar de não serem idênticas e possuírem características próprias, as duas esferas são sobrepostas. Nesse sentido, o interno e o externo devem ser vistos como duas extremidades de um eixo continuum, e não dimensões radicalmente demarcadas. Devido ao fato de a ação recíproca entre o doméstico e o internacional ser constante e complexa, e de ambos se encontrarem inter-relacionados, faz-se necessária uma abordagem que articule os dois níveis de análise.

Ao analisar as relações externas pelo ângulo do processo decisório doméstico, é possível observar como algumas características do sistema internacional são influenciadas por considerações políticas internas. Os sistemas se tornam bipolar ou multipolar, equilibrados ou desequilibrados, nuclearizados ou livres de armas nucleares, por causa da interdependência entre múltiplas decisões. Por isso, a política internacional não deve ser concebida com um fato dado, exógeno e pré-determinado, independente das escolhas dos atores. $\mathrm{Na}$ realidade, ela é formada pelas consequências agregadas de decisões individuais e coletivas. Uma análise incapaz de relacionar conjuntamente as esferas doméstica e internacional pode tornar-se pouco convincente. Assim, interpretaçóes abrangentes devem integrar a 
alta política das relações externas com as lutas cotidianas da política doméstica (Bueno de Mesquita, 2002; Hill, 2003).

Durante muitos anos, o realismo foi a abordagem dominante no estudo das relações internacionais. Em 1979, Kenneth Waltz publicou Theory of International Politics, criando o neorrealismo, também conhecido como realismo estrutural, uma variante do realismo clássico. Com sua teoria sistêmica, Waltz enfatizou as propriedades relacionais - poder econômico e militar - como os principais determinantes da ação internacional dos Estados. Estes foram definidos como atores unitários e iguais (like units), cujas características internas (instituições socioeconômicas, ideologia dos governos, liderança política) seriam irrelevantes. Ao sobrepor o sistema internacional (descentralizado e anárquico) ao sistema doméstico (centralizado e hierárquico), o neorrealismo relegou os condicionamentos internos a um plano inferior. Isso não quer dizer que esses condicionamentos não tivessem nenhum papel, pois os governantes, em suas decisões de política externa, seriam influenciados por fatores domésticos. No entanto, tais fatores eram vistos como um ruído desconcertante, uma fonte perturbadora de escolhas racionais (Amorim Neto, 2011; Waltz, 1979).

De acordo com Waltz (1996), nem realistas nem outras correntes teóricas acreditam que elementos domésticos (unit-level) sejam passíveis de exclusão de uma análise de política externa. A questão que se coloca não é o que pode ser excluído de uma abordagem de política externa, mas o que pode ser incluído em uma teoria de política internacional. Ainda segundo o autor, uma teoria sistêmica explica por que Estados similarmente posicionados se comportam de forma similar, apesar de suas diferenças internas. Já uma teoria de política externa "explicaria por que Estados posicionados de modo similar se comportam de diferentes maneiras. Diferenças de comportamento são oriundas de diferenças na composição interna" (Waltz, 1996, p. 54, tradução nossa). 
Ao contrário de Waltz, Graham Allison e Philip Zelikow (1999, p. 404-405) defendem que uma teoria de política externa é um componente inerente e inescapável de uma teoria de política internacional, da mesma forma que uma abordagem da esfera internacional é um elemento essencial de uma teoria sobre o comportamento dos Estados nesse plano. Ao invés de se concentrar apenas em simplificadas variáveis no nível sistêmico, uma análise mais abrangente exige a investigação dos múltiplos determinantes internos dos Estados e das interações entre esses fatores domésticos e determinadas características da dimensão internacional. Assim, a explicação dos eventos internacionais requer a sistemática identificação de fatores causais nos dois níveis.

Waltz (1979) critica Allison, cuja obra teve sua primeira edição em 1971, por confundir explicações sobre política internacional com explicações sobre política externa. Para o neorrealista, na taxonomia proposta por Allison, apenas o modelo I (ator racional) seria uma abordagem de política internacional. O modelo II (comportamento organizacional) e o modelo III (política governamental) seriam abordagens de política externa.

Deve-se destacar, todavia, que o mesmo Waltz, em $O$ homem, o estado e a guerra: uma análise teórica, de 1959, apresentou uma interpretação da política internacional bem diferente da obra de 1979, que envolvia três níveis de análise ou imagens: a primeira, baseada na natureza e no comportamento do homem; a segunda, na organização interna dos Estados; e a terceira, na estrutura da política mundial. As prescriçóes derivadas de uma única imagem seriam incompletas, apoiadas em análises parciais. A ênfase em uma determinada imagem distorceria a interpretação das outras. Dever-se-ia buscar, portanto, um nexo mais amplo de causas, visto que os Estados são moldados pelo contexto internacional, assim como os indivíduos são influenciados pelos ambientes nacional e internacional. Dessa forma, toda tentativa de compreender as relações internacionais deveria considerar as relações entre as três imagens (Waltz, 2004). 
Diante do domínio do realismo na área de relações internacionais, surgiu, entre as décadas de 1950 e 1960, a subdisciplina "análise de política externa". O novo campo desafiou algumas suposições caras ao realismo, com destaque para a concepção de Estado. Este era visto como um ator unitário, coerente, que buscava seus interesses nacionais de maneira clara e racional, com variados graus de sucesso de acordo com o talento de líderes particulares ou os constrangimentos circunstanciais. Devido ao enfoque no Estado (state-centric), a análise de política externa foi ironicamente rotulada de realista. No entanto, a subdisciplina foi responsável por criticar a noção de Estado como ator coletivo unitário, por meio de análises voltadas à política doméstica, às rivalidades burocráticas e ao papel dos indivíduos, além de ter incorporado aos seus estudos diversos atores não estatais. Desse modo, os analistas de política externa passaram a pesquisar os diferentes níveis de análise - indivíduo, Estado e sistema internacional - por considerarem que explicaçóes sobre fenômenos políticos não poderiam se restringir a apenas um deles (Alden e Aran, 2012; Beach, 2012; Hill, 2003).

Ao desafiar os pilares centrais do realismo, a análise de política externa procurou mostrar não apenas que sua abordagem - incorporando fatores domésticos - poderia oferecer uma consideração mais persuasiva da formulação da política externa e de suas irracionalidades, mas também que era preciso identificar as formas pelas quais os ambientes domésticos e os processos dos países eram afetados por fatores externos. Assim, a análise de política externa passou a investigar questóes relacionadas ao impacto do sistema internacional na política externa, à importância dos fatores domésticos em sua formulação e implementação e de que maneira diferentes processos decisórios afetavam as tendências e as ações da política exterior (Beach, 2012; Halliday, 2007).

O debate entre agência e estrutura é um dos temas subjacentes à análise de política externa. Por um lado, agência é toda ação de um determinado ator com o objetivo de mudar certo contexto 
de forma a favorecê-lo no alcance de suas metas; por outro, agente é toda entidade capaz de ações e decisões em qualquer contexto, compreendendo atores individuais ou coletivos, como os Estados e as organizações burocráticas. Já as estruturas são conjuntos de fatores que constituem os múltiplos ambientes nos quais os agentes atuam, criando constrangimentos e oportunidades, delimitando a natureza das escolhas e o contorno dos problemas enfrentados pelos diferentes atores. As estruturas podem ser de natureza material (ameaça militar) ou social (normas) e existem em diferentes níveis, desde a família até o sistema internacional. São entidades concretas ou conceituais. Não são algo fixo, pois representam processos ou padrões de interação, encontrando-se em transformação constante (Alden e Aran, 2012; Beach, 2012; Hill, 2003).

Os fatos da esfera internacional são causados pelas relações entre agentes e estruturas. Ambos se constituem mutuamente em um processo de interação contínuo. Ao analisar essa relação dinâmica do ponto de vista da formulação de política externa, Cristopher Hill (2003, p. 28) conclui que "foreign policy-making is a complex process of interaction between many actors, differently embedded in a wide range of different structures. Their interaction is a dynamic process, leading to the constant evolution of both actors and structures". ${ }^{1}$

Em vez de examinar os resultados das decisões de política externa, a análise de política externa, influenciada por abordagens behavioristas, procurou entender seu processo decisório. A política externa é produto da agência humana, e os indivíduos em posição de liderança estão em condição de identificar questôes importantes, fazer julgamentos sobre elas e agir com base em informações levantadas. São os líderes, e não os Estados, que escolhem as ações

${ }^{1}$ O trecho correspondente na tradução é: "a formulação de política externa é um complexo processo de interação entre muitos atores, diferentemente intrincados em uma vasta gama de distintas estruturas. Sua interação consiste em um processo dinâmico, levando a uma constante evolução de ambos, atores e estruturas". 
e tomam as decisões. Segundo Bruce Bueno de Mesquita (2002), não é possível compreender os constrangimentos e as motivações que moldam a política e a economia internacional sem levar em consideração os líderes e seus ambientes domésticos. Assim, a personalidade de diferentes líderes pode exercer influências distintas sobre a política externa de seus respectivos países.

Antes de sua prisão pela ditadura fascista, Antonio Gramsci publicou algumas reflexões sobre a necessidade de os Estados terem líderes e a relação destes com seus liderados. Para o pensador sardo, nenhum Estado poderia deixar de ter um governo formado por um número restrito de pessoas, as quais, por sua vez, se organizavam em torno de um homem dotado de maior capacidade e clarividência. Segundo Gramsci (2004, p. 235), enquanto houvesse a necessidade de um Estado, enquanto fosse historicamente necessário governar os homens, surgiria o problema - qualquer que fosse a classe dominante - de ter líderes, de ter um "líder".

No passado, alguns autores clássicos refletiram sobre os graus de liberdade da ação individual. Em O Principe, Nicolau Maquiavel (1999) conclui que a fortuna arbitra metade das ações humanas, deixando a outra metade para o livre-arbítrio. Assim, a circunstância, aquilo que não pode ser governado pelo homem, proporciona a chave para o êxito da ação política, desde que o indivíduo saiba agir dentro dos espaços abertos em uma dada situação concreta. Tempos depois, Karl Marx (1997, p. 21) inicia sua magistral análise sobre os acontecimentos que levaram ao golpe de Luís Bonaparte afirmando que "os homens fazem sua própria história, mas não a fazem como querem; não a fazem sob circunstâncias de sua escolha e sim sob aquelas com que se defrontam diretamente, legadas e transmitidas pelo passado". Nos dois casos, é possível observar o peso das estruturas e das contingências históricas sobre a capacidade de ação dos indivíduos.

$\mathrm{Na}$ tentativa de compreender o processo decisório, o modelo de escolha racional procura explicar uma ação intencional que visa 
à consecução de um objetivo capaz de maximizar um valor ou uma utilidade esperada pelo agente. A agência é atribuída a um governo concebido como ator racional unitário, análogo ao indivíduo. Em termos sintéticos, a decisão racional seria aquela feita a partir de um conjunto de alternativas, cada uma delas contendo suas respectivas consequências. Os atores envolvidos no processo decisório, todavia, não decidem sempre racionalmente, conforme os postulados centrais do realismo ou das teorias de escolha racional. Para os críticos da racionalidade, o modelo não é uma representação exata do mundo no qual os formuladores de política externa atuam. Os homens não agem no vácuo nem as instituições são monolíticas. Como todas as simplificações, tratar Estados como se fossem indivíduos racionais obscurece mais do que revela. Uma análise mais abrangente, pois, deve levar em consideração os constrangimentos dos múltiplos ambientes que afetam os formuladores de política externa - psicológico, burocrático, político, externo (Alden e Aran, 2012; Allison; Zelikow, 1999; Amorim Neto, 201; Beach, 2012; Hill, 2003).

No livro sobre a crise dos mísseis de outubro de 1962 , Graham Allison e Philip Zelikow (1999) apontam os limites do modelo do ator racional. Apesar de reconhecerem sua utilidade em certas situações, o modelo negligencia o impacto da burocracia e da disputa política nos processos de formulação e implementação de política externa. Diante dessa lacuna, os autores propõem dois modelos alternativos: comportamento organizacional e política governamental.

De acordo com o modelo de comportamento organizacional ou modelo II, os sujeitos não são entidades homogêneas. Os governos são concebidos como um vasto conglomerado de organizações (agências, ministérios, secretarias) - cada uma com sua dinâmica interna -, as quais lidam com os problemas de modo quase independente, o que significa que as prioridades e os temas governamentais são tratados de maneira paroquial ou míope pelas burocracias. A fim de facilitar a coordenação interburocrática, é preciso haver pro- 
cedimentos operacionais padrão (Standard Operating Procedures - SOP), que consistem em regras, normas e rotinas. Uma análise de decisões de política externa baseada nesse modelo exige especial atenção ao esforço de coordenação da liderança política, que pode até influir, mas não controlar totalmente o comportamento das diferentes organizações, que sempre conservam certo grau de autonomia (Allison e Zelikow, 1999; Amorim Neto, 2011).

Segundo o modelo da política governamental, ou modelo III, o comportamento dos governos não deve ser entendido como produto (output) das organizações burocráticas, mas como resultado das barganhas e disputas políticas. A exemplo do modelo anterior, mas diferentemente do primeiro, o aparato de cada governo nacional é retratado como uma complexa arena em que se disputam decisões de política externa. Os líderes políticos ocupam posições no topo das principais organizações, formando uma espécie de círculo decisório central. Para além desse núcleo, encontram-se sucessivos círculos concêntricos envolvendo desde outros escalóes e poderes do Estado até grupos da sociedade civil (imprensa, legisladores, lobistas, organizações não governamentais), atores estes que formam diferentes coalizões políticas para produzir o resultado almejado. Nesse modelo, as decisões governamentais surgem como uma colagem de diversos jogos particulares. Para explicar por que determinada decisão foi tomada, é preciso identificar os jogos e os atores de cada coalizão, com suas crenças e seus valores. As decisões de política externa são, portanto, a resultante de um paralelogramo de forças geradas pelas preferências e recursos de jogadores posicionados dentro da máquina estatal. Assim, a política externa torna-se a extensão da política por outros meios. e a luta política é o mecanismo de escolha da opção a ser adotada (Allison e Zelikow, 1999; Amorim Neto, 2011).

Apesar de apresentados como modelos distintos, alguns críticos não entenderam se o modelo III era separado ou uma mera extensão do modelo II, resultando em uma espécie de fusão entre ambos, que ficou conhecida como teoria da política burocrática. 
Chris Alden e Amnon Aran (2012) identificaram alguns limites da teoria da política burocrática, como, por exemplo, a pouca atenção para certos determinantes não burocráticos: desde fatores cognitivos, axiológicos e o tipo de Estado no qual os burocratas atuam (autoritário/democrático), passando pelo impacto de grupo de interesse e do congresso, até o papel da opinião pública. Ademais, o modelo exageraria o impacto da burocracia sobre a agência humana, convertendo os indivíduos em meros instrumentos de procedimentos burocráticos.

Outras críticas ao modelo de política burocrática se referem à redução das preferências dos indivíduos aos papéis ou cargos exercidos na burocracia. Os líderes ou funcionários acabam sendo retratados como robôs completamente limitados por sua posição no aparelho administrativo, quando na realidade os cargos ocupados nas organizações tanto podem constranger quanto permitir diferentes cursos de ação. Os valores e os objetivos individuais também conferem um importante elemento de indeterminação das escolhas efetuadas no âmbito de determinada organização. Tais críticas denunciam os limites estreitos da visão de política do modelo. Além disso, é preciso levar em consideração as circunstâncias particulares, os períodos históricos e os contextos políticos nos quais a política burocrática ocorre (Hill, 2003).

Em que pese as críticas, a teoria da política burocrática fez contribuições relevantes ao estudo da política exterior, já que o modelo representou um esforço de integração dos níveis doméstico e internacional na análise de política externa. Ao realçar a importância da dimensão doméstica, a abordagem desafiou o ceticismo do realismo e colocou questões centrais da política interna na agenda das relações internacionais. Ademais, tornou mais complexas as análises sobre o processo decisório. Em vez de restritas a um ator racional e unitário, as decisões de formulação e implementação de política externa passaram a ser vistas como resultado da disputa entre diferentes organizações e atores políticos. 
Juntamente com o livro de Allison e Zelikow, o artigo de Robert Putnam (1988) é um dos mais importantes textos sobre os nexos entre política interna e externa. De acordo com o autor, a política de muitas negociações internacionais pode ser concebida como um jogo de dois níveis. No plano internacional, ou nível I, ocorre a fase de negociação, na qual os governos nacionais buscam maximizar sua capacidade de dirimir pressões domésticas enquanto tentam minimizar consequências adversas no processo de negociação. Já no plano interno, ou nível II, responsável pela ratificação do acordo, atores domésticos defendem seus interesses e pressionam o governo, ao mesmo tempo que políticos buscam maximizar seu poder e construir coalizões com grupos de interesse.

A melhor maneira de entender o comportamento dos responsáveis pela tomada de decisão em política externa é reconhecer que eles operam em dois ambientes separados, cada qual com sua lógica, porém sobrepostos e potencialmente conflitantes. Dessa forma, afastam-se explicações baseadas em um único fator ou dimensão, além de ser possível observar o espaço aberto para que a liderança política possa atuar e fazer a diferença. Um possível acordo, portanto, somente pode ser alcançado quando o seu resultado reflete os interesses compartilhados de todos os atores relevantes e se encontra em sintonia com os imperativos da esfera doméstica, o que exige esforço, habilidade e criatividade política (Alden e Aran, 2012; Hill, 2003).

Outro aspecto fundamental do jogo de dois níveis de Putnam é a possibilidade de o líder político do país A tentar influenciar a base política do país $\mathrm{B}$, alterando as expectativas dos grupos domésticos do país B, que podem pressionar seu líder a aceitar um acordo. Nada impede também que as bases políticas dos dois países, devido a uma afinidade ideológica, por exemplo, interajam diretamente, afetando as negociações entre os dois governantes. Assim, é possível observar como o modelo analítico proposto por Putnam é altamente plástico e politizado, exatamente o contrário do neorrealismo, com sua rigidez estruturalista (Amorim Neto, 2011). 
A literatura em relações internacionais contém inúmeros argumentos sobre a importância da dimensão doméstica. Ocorre que as principais abordagens enfatizam os aspectos formais ou procedimentais dos relacionamentos entre os mais variados grupos internos, omitindo a política. Sem dúvida, as abordagens sobre a força ou a fraqueza dos Estados e de suas estruturas institucionais são importantes politicamente, pois afetam a possibilidade de realização de certas ações. No entanto, a ênfase nos procedimentos ou nas capacidades estatais obscurece as maneiras pelas quais a política impacta os resultados. Para evitar esse reducionismo, é preciso analisar as coalizões políticas, e, assim, os valores e os interesses que elas mobilizam para atingir seus objetivos e fazer com que determinadas decisões sejam adotadas pelos governos (Gourevitch, 1978).

Peter Gourevitch (1993) chamou de conjuntura crítica a combinação simultânea de transformações sistêmicas e domésticas. Essas conjunturas são momentos nos quais os padrões dominantes de desenvolvimento doméstico e inserção internacional se esgotam e abrem espaço para o surgimento de uma nova coalizão sociopolítica, com reflexos na política econômica e na política externa. $\mathrm{O}$ autor observa que os tempos de prosperidade obscurecem a importância do poder e da política que lhe conferem sustentação. Em tempos de crise, contudo, ficam claras as escolhas feitas entre as propostas conflitivas que surgem da política. Ao verificar as relações entre crises econômicas e formação de coalizões políticas, Gourevitch (1993) destaca a importância dos seguintes fatores que se interpõem entre ambos: em primeiro lugar, os mecanismos de representação, como os partidos, as associações e os grupos de interesse; em segundo, a política é afetada pela organização do Estado e sua burocracia; em terceiro, os atores são afetados pela ideologia e pelos modelos econômicos existentes; por fim, as coalizões políticas formadas são influenciadas pela posição do país no sistema estatal internacional. Ao analisar as coalizões políticas e suas ideias, chega-se à influência dos partidos políticos no processo decisório de política 
externa. Um exame das relações entre partido e política exterior revela que a escolha de determinadas políticas é influenciada pela orientação ideológica partidária, e não do governo. Os partidos políticos utilizam suas fundações e redes internacionais como meios de complementar e até mesmo criticar a linha política defendida pelo ministério de relações exteriores. Nesse sentido, as secretarias de relações internacionais dos partidos exercem alguma forma de política internacional que pode influenciar a política externa do país (Alden e Aran, 2012).

No caso brasileiro, por exemplo, o amadurecimento da política internacional do PT e a evolução do debate interno no Itamaraty são dois processos que se interligam de modo sutil por variados laços. No entanto, a relação entre partido e Itamaraty não se limita aos governos petistas. Ao identificar o presente como politizado ou ideologizado, corre-se o risco de despolitizar a política externa pretérita, o que significa aceitar a tese equivocada da separação estanque entre burocracia e política (Pinheiro e Milani, 2012; Cruz, 2010).

As abordagens estruturalistas tendem a enfatizar os efeitos do sistema internacional na política doméstica. A complexificação das relações internacionais, entretanto, exige que se analise como a dimensão interna, dificilmente monocromática, pode influenciar o comportamento de determinado país na esfera mundial. A multiplicidade de temas tem obrigado alguns ministérios "domésticos" e atores não estatais a participar do processo decisório de política exterior. Questões geralmente classificadas como internacionais - comércio, defesa, dívida externa, imigração e tarifa - envolvem decisões e interesses nos dois níveis. Observa-se, portanto, uma crescente internacionalização da política doméstica, fazendo com que se deva abandonar a ideia do processo de formulação de política externa como uma área totalmente distinta de outras temáticas (Hill, 2003; Ingram e Fiederlein, 1988).

No mundo pós-Guerra Fria, marcado pela liberalização econômica, parece superada a ideia realista de que a política externa 
começa onde termina a política doméstica. Na realidade, os contornos da política externa são afetados pelo jogo estratégico entre atores domésticos na luta pelo poder. Isso significa que o chamado "interesse nacional" depende das preferências e dos interesses da coalizão política vencedora, e não apenas pode mudar, como também é objeto de conflito interno (Lima, 2000; Pinheiro e Milani, 2012).

O processo de internacionalização da economia e a democratização da sociedade são fatores que contribuem para a politização da política externa. Por um lado, há a contribuição por parte da integração à economia internacional e da abertura econômica em função dos impactos distributivos internos da maior participação no comércio internacional, visto que em uma economia aberta há ganhos e perdas distintos para os diferentes interesses setoriais. ${ }^{2}$ Por outro, a democratização política permite a intensificação do debate de ideias e das discussões entre atores sociais distintos quanto à melhor forma de contemplar suas demandas. Assim, a pluralidade de atores e de suas visões contribui igualmente para a politização das agendas de política externa (Lima, 2000; Pinheiro e Milani, 2012).

Durante longo período, a política externa tendeu a ser considerada desconectada das demais políticas públicas, pois carregava sobre si uma áurea de particularidade, especialização e confidencialidade que a tornava acessível apenas a alguns poucos "especialistas" capazes de operá-la. No entanto, a reflexão acadêmica brasileira e internacional tem enfatizado cada vez mais a dimensão de política pública da política externa (Lima e Milani, 2014). De acordo com Letícia Pinheiro e Carlos Milani (2012, p. 334),

2 Segundo Maria Regina Soares de Lima (2000, p. 289), "quando, ao contrário, os custos e benefícios não se concentram em setores específicos, ou os resultados da ação externa são neutros do ponto de vista do conflito distributivo interno, a política externa produz bens coletivos, aproximando-se do seu papel clássico, de defesa do interesse nacional ou do bem-estar da coletividade". 
Ao assumirmos a política externa como uma política pública, estamos, portanto, trazendo a política externa para o terreno da politics, ou seja, reconhecendo que sua formulação e implementação se inserem na dinâmica das escolhas de governos que, por sua vez, resultam de coalizões, barganhas, disputas, acordos entre porta-vozes de interesses diversos, que expressam, enfim, a própria dinâmica da política. Em decorrência, estamos retirando a política externa de uma condição inercial associada a supostos interesses nacionais autoevidentes e/ou permanentes e protegidos das injunções conjunturais de natureza político-partidária. Portanto, estamos privando a política externa das características geralmente atribuídas (ou preconcebidas) ao que se chama de política de Estado, que nos levava a imputar à política externa uma condição de extrema singularidade em relação às demais políticas públicas do governo.

Em algum momento, as políticas de Estado foram e são políticas de governo. Com a política externa brasileira não é diferente. Como toda política pública, ela sofre mudanças em suas agendas e em seus atores por motivos sistêmicos e de acordo com as agendas dos governos. $\mathrm{O}$ insulamento burocrático de qualquer agência do Estado democrático e de direito enfraquece a sua capacidade de formulação e gestão legítimas de políticas governamentais. No caso do Brasil, a hipótese do insulamento burocrático do Itamaraty não expressa mais a realidade empírica da política exterior do país em tempos de globalização e democratização do Estado, processos políticos que contribuem para tornar as agendas decisórias mais complexas, levando à participação de outras instituições públicas e diversos setores da sociedade civil (Lima e Milani, 2014; Pinheiro e Milani, 2012). ${ }^{3}$

3 Muitos analistas afirmam que a trajetória de continuidade da política externa brasileira faria dela uma política de Estado. Durante muitos anos, a busca do desenvolvimento econômico tornou-se um dos principais vetores da política 
Em resumo, a literatura discutida até o momento oferece uma série de elementos plausíveis a respeito dos determinantes da política externa, que é constituída por fatores internos e externos. Para compreender o processo decisório da política externa, é preciso um modelo analítico que consiga articular as dimensões doméstica e internacional. Nesse sentido, procurou-se enfatizar as fontes domésticas da política externa, destacando-se o papel das coalizóes políticas e das disputas internas na formulação e na orientação de uma determinada política exterior. Apesar das contribuições dos estudos de análise de política externa e de política burocrática, torna-se imprescindível analisar o sistema internacional para entender de que maneira as relações assimétricas de poder impactam a margem de manobra dos atores domésticos e condicionam o tipo de inserção de determinado país no sistema mundial.

\subsection{Estado, capitalismo e assimetrias no sistema internacional}

Desde os albores do capitalismo, observam-se formas muito diversas de entrelaçamento entre política e economia, poder e dinheiro. Há muitas análises consistentes sobre a variabilidade nos imbricamentos e distanciamentos entre a ordem política e a atividade econômica no mundo capitalista. Nesse sentido, o surgimento de um sistema de Estados soberanos no noroeste da Europa do século XVII foi resultado de um processo histórico muito específico, associado ao advento de novas formas produtivas por meio do impulso comercial propiciado pela expansão além-mar. No entanto, a origem histórica do sistema capitalista europeu não começa pelo

exterior do Brasil. A íntima vinculação entre o modelo desenvolvimentista e a política exterior resistiu a mudanças de regime e a rupturas institucionais (Cervo, 2003; Vigevani e Cepaluni, 2011). Além disso, o Itamaraty representa uma das bases da autonomia e do poder da burocracia pública brasileira. Isso significa que as mudanças promovidas pelos governos na área de política externa costumam ocorrer sem fortes rupturas com a tradição diplomática. 
mercado mundial nem pelo jogo de trocas, mas pela articulação entre a acumulação de poder e de capital.

Enquanto nos impérios asiáticos a relação dos poderes soberanos com a atividade mercantil e financeira era muito frouxa, algumas características históricas do Ocidente possibilitaram uma aliança cada vez mais estreita e multiforme entre o poder e o capital (Fiori, 2007). De acordo com Max Weber (2006), a supressão das barreiras existentes entre economia interna e externa, entre moral dentro e fora da estirpe, a penetração do princípio mercantil na economia interna e a organização do trabalho sobre essa base constituem características próprias ao capitalismo ocidental. Além disso, somente o Ocidente conheceu o Estado em seu sentido moderno, ou seja, com administração orgânica e relativamente estável, funcionários especializados e direitos políticos. No Oriente, por sua vez, essas instituições não alcançaram pleno desenvolvimento.

O capitalismo apresenta-se em forma diferente nos diversos períodos da história. Todavia, a satisfação das necessidades cotidianas, baseada em técnicas capitalistas, só foi peculiar no Ocidente. Nos países ocidentais, isso ocorreu desde a segunda metade do século XIX. Uma condição prévia para a existência do capitalismo moderno foi a criação da contabilidade racional do capital; quanto mais racional, mais o capitalismo se apoiava na venda para grandes massas e na possibilidade de abastecê-las, que, elevado à categoria de sistema, apenas se alcançou no desenvolvimento moderno ocidental. A partir desses elementos e de outros, Weber (2006, p. 321) conclui que "decisivamente, o capitalismo surgiu através da empresa permanente e racional, da contabilidade racional, da técnica racional e do direito racional. A tudo isto se deve ainda adicionar a ideologia racional, a racionalização da vida, a ética racional na economia”.

Ao contrário do discurso liberal hegemônico, que costuma minimizar as relações de poder, a violência do Estado foi essencial para a consolidação do capitalismo. Equivocadamente, os liberais interpretam as instâncias em que a força não é visível como prova de ausência 
de poder (Waltz, 2004). No entanto, a experiência histórica ensina que, por trás de toda economia, existe um elemento coercivo - atualmente manejado pelo Estado, em outros tempos pelas corporações. Essa coerção, todavia, não é precisamente uma atuação econômica, apenas um meio para assegurá-la (Weber, 2006).

No século XIX, Marx elaborou a mais abrangente e incisiva crítica à economia política. No capítulo 24 de $O$ capital, Marx (2013) narra de que maneira os diferentes momentos da acumulação primitiva foram combinados de modo sistêmico na Inglaterra de fins do século XVII, dando origem ao sistema colonial, ao sistema da dívida pública, ao moderno sistema tributário e ao sistema protecionista. ${ }^{4}$ Todos eles lançaram mão do poder do Estado, da violência concentrada e organizada da sociedade, com o propósito de impulsionar o processo de transformação do modo de produção feudal em capitalista. A violência estatal, portanto, ela mesma uma potência econômica, esteve na origem da nova sociedade capitalista.

Ao separar a economia da política, a narrativa liberal atribuiu o domínio da "concorrência pacífica" à primeira e o terreno da violência à segunda. De acordo com essa interpretação, a violência foi apenas uma manifestação mais ou menos fortuita da "política externa”, dissociada do domínio econômico do capital. Para Rosa Luxemburgo (1985), entretanto, a violência tornou-se o veículo do processo econômico, pois ambos os aspectos da reprodução do capital se encontravam organicamente interligados. Além do processo de acumulação primitiva na Europa, constituem exemplos dessa histórica relação a colonização das Américas e, posteriormente, o neocolonialismo na África e na Ásia.

\footnotetext{
4 Segundo Marx (2013, p. 786), “a assim chamada acumulação primitiva não é, por conseguinte, mais do que o processo histórico de separação entre produtor e meio de produção. Ela aparece como 'primitiva' porque constitui a pré-história do capital e do modo de produção que lhe corresponde”. Além desse significado, o conceito de "acumulação primitiva” se aplica também ao papel da espoliação colonial no processo histórico que viabilizou o advento do capitalismo moderno, isto é, industrial.
} 
Entre os séculos XVI e XVIII, a escravidão foi um fator central para o processo de acumulação de riquezas dentro da Europa. Em 1674, a Companhia das Índias Ocidentais, ou WIC (West-Indische Compagnie), que havia sido criada em 1621 pelos holandeses, foi reorganizada como uma empresa de tráfico de escravos. A WIC foi responsável pela criação do comércio triangular do Atlântico, que viria a interligar as comunidades manufatureiras da Europa, os grupos de aliciadores de escravos da África e os colonos das Américas, formando o mais lucrativo circuito de comércio e produção. Todavia, o grande beneficiário dessa inovação não foi a WIC, mas os comerciantes particulares franceses e, sobretudo, ingleses. Ademais, a Inglaterra conseguiu arrancar dos espanhóis, na paz de Utrecht (1713),, o privilégio de explorar oficialmente o tráfico de escravos entre a África e a América espanhola. Assim, sem o desenvolvimento inicial do comércio triangular do Atlântico pela WIC, teria faltado um componente dinâmico preponderante na expansão industrial inglesa do século XVIII (Arrighi e Silver, 2001; Marx, 2013; Weber, 2006).

De diferentes maneiras, o Estado tem sido crucial como mecanismo para otimizar a acumulação de capital. Após o Tratado de Vestfália (1648), ${ }^{6}$ os Estados nacionais tornaram-se as unidades políticas básicas no sistema mundial eurocêntrico. Os tratados substituíram a concepção de uma autoridade imperial/papal supraes-

5 O Tratado de Utrecht (1713) colocou fim à Guerra de Sucessão Espanhola, iniciada em 1701. Durante a guerra, houve combates entre França e Grã-Bretanha tanto na América e na Índia quanto no alto mar. O Tratado estabeleceu a Grã-Bretanha como a principal potência colonial e confirmou o declínio da posição relativa da Espanha dentro da Europa (Tilly, 1996).

${ }^{6}$ O Tratado de Vestfália (1648) encerrou a Guerra dos Trinta Anos (1618-48) e reuniu 145 representantes das mais diversas partes do nascente sistema estatal europeu. Além de reconhecer a independência da República Holandesa e congelar as divisões existentes entre Estados católicos e protestantes, o tratado impediu definitivamente a consolidação de um império dos Habsburgos e tornou improvável que qualquer outro império pudesse expandir-se dentro do continente. Assim, o acordo de paz que colocou fim à Guerra dos Trinta Anos consolidou o sistema europeu de Estados nacionais (Tilly, 1996). 
tatal pela ideia de que os Estados europeus formavam um único sistema político, baseado no direito internacional e no equilíbrio de poder - direito e poder que operavam mais entre do que acima dos Estados. As regras do nascente sistema interestatal não foram definidas por consentimento ou consenso. $\mathrm{Na}$ realidade, dependeram da disposição e da capacidade dos Estados mais fortes de impô-las, primeiro aos Estados mais fracos e em seguida uns aos outros. Os Estados, portanto, situam-se em uma hierarquia de poder. Dessa forma, o sistema vestfaliano, como outros sistemas internacionais, é caracterizado por normas em disputa, pela ausência de estruturas de autoridade universal e pela assimetria de poder (Arrighi e Silver, 2001; Krasner, 2001; Wallerstein, 2001).

Em sua obra clássica sobre a formação dos Estados europeus, Charles Tilly (1996) afirma que o sistema de Estados que predomina atualmente no mundo tomou forma na Europa após 990 d.C. No entanto, levou muito tempo para que o mapa europeu fosse dominado pelos Estados nacionais, definidos pelo autor como organizações relativamente centralizadas, diferenciadas e autônomas que reclamavam prioridade no uso da força dentro de territórios amplos, contíguos e claramente circunscritos. Ao longo dos séculos, os Estados nacionais acabaram absorvendo, eclipsando ou eliminando todos os seus concorrentes, como as cidades-Estado e os impérios, além dos sistemas centralizados que existiam na China, na Índia, na Pérsia e na Turquia. Segundo Tilly (1996, p. 112), isso ocorreu porque:

[...] a escala crescente da guerra e o entrelaçamento do sistema europeu de Estado através de relações comerciais, militares e diplomáticas acabaram por conferir, na guerra, uma vantagem àqueles estados que podiam dispor de grandes exércitos permanentes; os Estados que tinham acesso a uma combinação de grandes populações rurais, capitalistas e economias relativamente comercializadas venceram as guerras. Estabeleceram os termos da guerra, e a sua 
forma de Estado passou a predominar em toda a Europa. No final, os Estados europeus convergiram nesta forma: o Estado nacional.

A expansão competitiva dos Estados nacionais criou impérios coloniais e internacionalizou a economia capitalista, sem eliminar, contudo, os entes estatais e as economias nacionais. Nesse paradoxo, esconde-se a contradição político-econômica mais relevante do sistema mundial moderno. Os Estados que se expandem, conquistando ou submetendo novos territórios, expandem igualmente seu "território monetário" e internacionalizam seus capitais. Porém, ao mesmo tempo, seus capitais e sua riqueza se expressam em suas moedas nacionais e só podem se internacionalizar mantendo seu vínculo com alguma moeda nacional, a sua própria ou a de um Estado mais poderoso. Por essa razão, pode-se afirmar que a globalização econômica é um traço originário e constitutivo do sistema capitalista, mas não é uma obra do "capital em geral", nem representa o fim dos Estados e das economias nacionais. Ademais, o capitalismo não inventou as hierarquias (como não criou também o mercado ou o consumo), mas as tem utilizado. Por isso, há, no sistema capitalista internacional, tanto uma hierarquia de Estados como uma hierarquia de moedas (Braudel, 1987; Fiori, 2007).

É ocioso especular se o capitalismo teria se desenvolvido sem o papel ativo desempenhado pelo Estado moderno. No capitalismo histórico, os capitalistas confiaram em sua capacidade de utilizar os aparatos estatais em seu benefício. É provável que o sistema do capital não sobrevivesse uma única semana sem o forte apoio que recebe do Estado (Mészáros, 2003; Wallerstein, 2001). Por isso, Fernand Braudel (1987, p. 55) tem razão quando afirma que "o capitalismo só triunfa quando se identifica com o Estado, quando ele é o Estado". Se a ascensão de Amsterdam no século XVII significou o triunfo da Bolsa de Valores (fluxo contínuo) sobre as feiras (encontros intermitentes), a hegemonia da Inglaterra marcou o fim da economia citadina e o advento de um mercado nacional. Afinal, Braudel conclui, Londres não era uma cidade-Estado, mas a capital 
de uma irresistível economia nacional, ou seja, de um espaço econômico coerente, unificado, cujas atividades podiam encaminhar-se em conjunto e numa mesma direção.

A transição para o capitalismo no noroeste da Europa constituiu simultaneamente um sistema internacional, baseado nos Estados nacionais, e um sistema transnacional, integrado a um mercado global em formação, nos marcos do qual a nova forma de produção se generalizou (Fernandes, 1998). No Manifesto Comunista, Marx e Engels (1997) analisaram a maneira pela qual a burguesia revolucionava permanentemente os instrumentos de produção e todas as relações sociais; o modo como a nova classe arrastava e integrava todas as nações para o nascente mercado mundial. Nesse sentido, Hannah Arendt (1989, p. 168) está certa quando, contrariando Lênin, afirma que "o imperialismo deve ser considerado o primeiro estágio do domínio político da burguesia e não o último estágio do capitalismo".

No século XIX, o recém-consolidado capitalismo europeu aproveitou o poder concentrado dos grandes Estados centralizados para subordinar o conjunto do planeta à sua dinâmica, a princípio por meio de uma agenda universal liberalizante e, posteriormente, pela construção de impérios coloniais concorrentes. Desde o início, pois, ocorreu uma articulação tensa e contraditória entre as dimensões global e nacional (Fernandes, 1998).

A partir de 1884, o imperialismo - surgido do colonialismo e gerado pela incompatibilidade do sistema de Estados nacionais com o desenvolvimento econômico e industrial do último terço do século XIX - iniciou a sua política de expansão, que diferia tanto das conquistas de característica nacional, antes levadas adiante por meio de guerras fronteiriças, quanto da política imperialista que levou à formação de impérios ao estilo romano. Em seu opúsculo de 1917, Lênin definiu o imperialismo como o estágio monopolista do capitalismo, caracterizado, de um lado, pela partilha econômica do mundo pelos grupos capitalistas e, de outro, pela partilha ter- 
ritorial do planeta pelos Estados e seus líderes políticos (Arendt, 1989; Lênin, 2012).

A expansão como política permanente é a ideia central do imperialismo, que surgiu quando a classe detentora da produção capitalista rejeitou as fronteiras nacionais como barreira à expansão econômica. Desde o início, a burguesia compreendeu que somente o acúmulo ilimitado de poder poderia levar ao acúmulo ilimitado de capital; somente a expansão dos instrumentos nacionais de violência poderia racionalizar os investimentos no estrangeiro. Dessa forma, tanto a expansão - como objetivo final da política externa - quanto a concorrência passaram a se basear exclusivamente na força política. Assim, quando o acúmulo de poder atingiu seus limites nacionais, a burguesia percebeu que apenas com uma ideologia expansionista, apoiada na ideia de "progresso", seria possível colocar novamente o motor em funcionamento (Arendt, 1989).

Nos dias de hoje, poucos aceitariam a teoria do subconsumo de Rosa Luxemburgo, pois é possível acumular mesmo diante de uma demanda efetiva em estagnação, desde que, por exemplo, os custos dos insumos (matérias-primas, terra, trabalho) sofram um declínio acentuado. A teoria da sobreacumulação, entretanto, oferece uma chave para compreender o movimento de expansão capitalista. A sobreacumulação em dado sistema territorial representa uma condição de excedentes de trabalho (desemprego elevado) e excedentes de capital (registrados como um acúmulo de mercadorias que não pode ser dissolvido sem uma perda e/ou como excedentes de capital monetário a que faltam oportunidades de investimento produtivo e lucrativo). Esses excedentes podem ser potencialmente absorvidos por deslocamentos temporais, a exemplo de investimentos de longo prazo ou gastos sociais; por deslocamentos espaciais, por meio da abertura de novos mercados e novas oportunidades de recursos em outros lugares; ou por uma combinação dos dois movimentos (Harvey, 2009).

As crises e as depressões que precederam a era do imperialismo foram agravadas pela resistência política da burguesia por ter renun- 
ciado a quaisquer privilégios mediante reformas sociais domésticas, o que resultou na incapacidade de absorção interna da sobreacumulação de capital e trabalho. Apesar de a tese do subconsumo não se aplicar, Rosa Luxemburgo estava certa ao defender que o processo histórico de acumulação de capital dependia das camadas e sociedades não capitalistas. Logo, a saída encontrada pelo sistema foi a exportação da força de trabalho supérflua e do capital excedente. A burguesia compreendeu que o "pecado original do roubo", que séculos antes tornara possível a "acumulação original", descrita por Marx, teria eventualmente de ser repetido, a fim de evitar que o motor da acumulação parasse de súbito. Ficou claro, portanto, que o capitalismo precisa dispor perpetuamente de algo "fora de si mesmo" para estabilizar-se. Nessa dialética "interior-exterior", observa-se de que maneira a relação orgânica entre reprodução expandida, de um lado, e processos de espoliação, do outro, tem moldado a geografia histórica do capitalismo (Arendt, 1989; Harvey, 2009; Luxemburgo, 1985).

O imperialismo capitalista surge a partir da fusão de duas lógicas opostas de poder: a "territorial" e a "capitalista". De um lado, encontram-se as estratégias políticas, diplomáticas e militares invocadas e usadas por um Estado em sua luta para afirmar seus interesses e realizar suas metas em âmbito mundial. Do outro, estão os processos de acumulação do capital no espaço e no tempo. Nas duas lógicas, os interesses e as motivações dos agentes são divergentes. Enquanto o político opera num espaço territorializado, o capitalista atua em espaço e tempo contínuos. Ademais, enquanto os Estados estão confinados a fronteiras territoriais fixas e raramente mutáveis, as empresas capitalistas vêm e vão, mudam de localização com facilidade, fundem-se ou encerram as suas operações. Em todo momento histórico-geográfico, uma ou outra dessas lógicas pode predominar. No entanto, o que distingue o imperialismo capitalista de outras concepções do império é a predominância da lógica capitalista, embora haja momentos em que a lógica territorial venha para o primeiro plano (Arrighi, 1996; Harvey, 2009). 
Apesar de diferirem entre si, as lógicas territorial e capitalista entrelaçam-se de formas complexas e por vezes contraditórias. De modo equivocado, a literatura sobre o imperialismo supõe com frequência um fácil acordo entre as duas. Todavia, a relação entre ambas deve ser vista como problemática e, muitas vezes, contraditória, ou seja, dialética. Do ponto de vista da lógica capitalista, as práticas imperialistas referem-se à exploração das condições geográficas desiguais sob as quais ocorre a acumulação do capital, aproveitando-se igualmente das assimetrias advindas das relações espaciais de troca. A condição de igualdade presumida em mercados de funcionamento perfeito é violada, e as desigualdades resultantes adquirem expressão espacial e geográfica específica. A riqueza e o bem-estar de territórios particulares aumentam em detrimento de outros espaços. Assim, as condições geográficas desiguais não advêm apenas de diferentes dotações de recursos naturais ou vantagens de localização; elas são produzidas, sobretudo, pelas maneiras desiguais em que a própria riqueza e o próprio poder se tornam altamente concentrados em certos lugares, em decorrência de relações assimétricas de troca. É nesse momento que a dimensão política retorna à cena, porquanto uma das tarefas essenciais do Estado é tentar preservar o padrão de assimetrias espaciais de troca que lhe seja vantajoso. Em suma, o Estado é a entidade política mais capacitada para orquestrar esses processos, e sua tarefa é manter as lógicas territorial e capitalista do poder sempre interligadas, ainda que não necessariamente convergentes (Harvey, 2009).

As relações de assimetria ganharam um olhar próprio na periferia do sistema internacional. Raúl Prebisch e Celso Furtado foram os principais responsáveis pela elaboração de um pensamento original, o estruturalismo histórico, que contribuiu para o surgimento de uma análise sistêmica do desenvolvimento desigual do capitalismo como sistema econômico mundial organizado hierarquicamente. As ideias da CEPAL, criada em 1947, representaram uma abordagem original sobre o desenvolvimento internacional. A nova organiza- 
ção ofereceu uma teoria própria de desenvolvimento, com base nas condições reais e na história da região, desafiando a teoria liberal ortodoxa dominante, que justificava a divisão internacional do trabalho imposta pela hegemonia britânica.

A teoria do desenvolvimento da CEPAL analisou a particularidade do processo de transformação das economias periféricas, cuja trajetória era bem diferente da dos países que tinham passado pela Revolução Industrial. Ao contrário dos teóricos liberais e mesmo de autores keynesianos, incapazes de compreender a realidade da periferia, a CEPAL e seus principais formuladores recusaram-se a tratar como "anomalia” as especificidades da formação histórica dos países subdesenvolvidos. Pela primeira vez, o subdesenvolvimento foi visto como uma realidade específica de certas economias, que merecia um esforço de teorização também específico. Assim, o subdesenvolvimento passou a ser analisado como um processo histórico autônomo, e não uma etapa pela qual tenham passado as economias desenvolvidas, como defendia a teoria da modernização, que teve, em Walt Whitman Rostow e seu "manifesto não comunista" - The stages of economic growth -, um importante expoente (Bielschowsky, 2000; Cardoso e Faletto, 2011; Furtado, 2009, 2013).

A principal contribuição teórica da CEPAL foi a concepção centro-periferia da economia internacional. No sistema econômico mundial, o polo periférico deveria produzir e exportar matérias-primas e alimentos, enquanto os centros se encarregariam da produção e exportação dos bens industriais. Ao ligar esse mecanismo ao ciclo econômico, que começava no centro e se espalhava pela periferia, Prebisch argumentava que a distribuição dos benefícios era desigual, pois a dinâmica do comércio exterior favorecia os países industrializados, sobretudo durante as recessões. Além da vulnerabilidade ao ciclo econômico, Prebisch e Hans Singer tinham identificado, por meio de estatísticas históricas, uma tendência secular descendente nos preços dos produtos primários em relação aos preços dos produtos manufaturados. A realidade desmentia a teoria de comércio 
clássica, que pressupunha benefícios iguais para exportadores industriais e agrícolas e que supostamente tinha a mesma validade na América Latina e nos países desenvolvidos. Havia, portanto, uma assimetria inerente ao sistema, e as leis de mercado eram incapazes de resolver as grandes falhas nas relações centro-periferia, sobretudo as tendências excludentes do desenvolvimento periférico. Diante desse diagnóstico, a CEPAL passou a defender uma industrialização coordenada pelo Estado como estratégia para superar a pobreza e reverter a distância crescente entre centro e periferia (Bielschowsky, 2000; Dosman, 2011; Prebisch, 2011).

Para o sociólogo Francisco de Oliveira (2003), a denúncia feita por Prebisch e pela CEPAL sobre os mecanismos assimétricos do sistema econômico internacional poderia ter sido uma base para a reelaboração da teoria do imperialismo. Segundo o autor, uma vez abortada a possibilidade de tal reelaboração, a proposição resultante teria se mostrado nitidamente reformista e ingênua, apesar de altamente ética. No entanto, Oliveira não deveria esperar de uma comissão vinculada à Organização das Nações Unidas (ONU) e de um economista liberal heterodoxo propostas mais radicais. No contexto mundial atual, dominado pelo conservadorismo e por ideias neoliberais, faltam pensadores reformistas e originais como Prebisch e Furtado.

O estreito vínculo histórico entre o capitalismo e o moderno sistema interestatal é marcado pela tensão permanente. $\mathrm{O}$ desenvolvimento do capitalismo traz como resultado, de um lado, a internacionalização da vida econômica e, de outro, o agravamento da tendência à nacionalização dos interesses capitalistas. Nesse sentido, uma das contradições e limitações mais importantes do sistema está na relação entre a tendência globalizante do capital transnacional na esfera econômica e a dominação continuada dos Estados nacionais como estrutura abrangente de comando da ordem estabelecida. Qualquer ímpeto de hegemonia por parte de um Estado sofreria a resistência dos demais. Assim, o capitalismo histórico tem operado no interior de 
uma economia-mundo, mas não no de um Estado-mundo. É possível concluir, portanto, que o Estado racional com contornos definidos tem assegurado ao capitalismo as possibilidades de sua subsistência; enquanto não ceder lugar a um império mundial, o sistema capitalista deverá perdurar (Arrighi, 1996; Bukharin, 1984; Mészáros, 2003; Wallerstein, 2001; Waltz, 2004; Weber, 2006).

Alguns críticos afirmam que a espacialidade do poder não deve ser reduzida à territorialidade estatal. Sem dúvida, a noção de soberania deve ser revista diante dos sistemas transgressores de âmbito planetário, cujo exercício violento acentua a porosidade das fronteiras. Tais sistemas são, sobretudo, a informação e a finança, cuja fluidez se multiplica graças ao avanço da técnica contemporânea. As fronteiras estatais tornam-se altamente permeáveis aos fluxos de bens, ideias, investimentos e pessoas, que abrem esses territórios para influências que estão geograficamente além do alcance dos poderes governamentais. Em vez do fim da "geografia", a globalização permite sua reformulação que vai de encontro a um mosaico mais complexo formado por Estados, regiões, cidades e localidades diferentemente integradas na economia mundial. Além disso, deve-se destacar as redes corporativas globais, que vêm se tornando uma importante força não territorial. As múltiplas conexões e os diversos foros econômicos têm permitido um processo de socialização no qual as elites de diferentes países produzem e difundem normas e princípios que apoiam as atuais estruturas liberais de governança global (Agnew, 2005; Santos, 2007; Stephen, 2014).

Desde os anos 1980, com o avanço do neoliberalismo, houve esforços ideológicos e organizacionais investidos para superar a estrutura nacional de tomada de decisões. Nessa época, foi muito difundido o slogan superficialmente tentador "pense globalmente, aja localmente". No entanto, o "global" a que faz referência torna-se vazio sem as complexas relações com as comunidades nacionais. Além disso, uma vez que se divorcia o "global” de sua inserção nos múltiplos ambientes nacionais, desviando o foco das contraditó- 
rias relações que enredam os Estados, também o "local”, onde se espera agir, torna-se absolutamente míope e sem significado. Assim, a relação entre esses dois níveis é caracterizada por uma integração vertical, dependente e alienadora, uma vez que as decisóes essenciais concernentes aos processos locais são estranhas ao lugar e obedecem a motivações distantes (Mészáros, 2003; Santos, 2007).

O processo de globalização debilitou o Estado-nação, instituição central da política desde a superação dos demais concorrentes (cidade-Estado, impérios, ligas). Essa centralidade do Estado-nação devia-se tanto ao seu monopólio do poder da lei quanto ao seu papel como campo efetivo de ação política para a maioria dos fins. No final do século XX, entretanto, o Estado-nação se encontrava na defensiva contra uma economia mundial que não podia controlar; contra sua aparente incapacidade fiscal de manter os serviços para seus cidadãos; contra sua incapacidade real de manter o que, pelos seus próprios critérios, era sua maior função: a manutenção da lei e da ordem públicas. Apesar dessas debilidades, o Estado, ou alguma forma de autoridade pública representando o interesse público, era mais indispensável do que nunca, caso se quisesse enfrentar as iniquidades sociais e ambientais provocadas pela lógica da acumulação capitalista e pelas regras do mercado (Hobsbawm, 1995).

Apesar da visão constantemente difundida, globalização e Estado-nação são fenômenos que não se contradizem, mas, antes, são partes de um mesmo universo: o capitalismo contemporâneo. $\mathrm{O}$ século XX assistiu à multiplicação do número de Estados independentes, que eram cerca de sessenta em 1945 e agora são quase duzentos. Ao contrário do que é difundido, o Estado continua relevante e prova disso é que nem as empresas transnacionais nem as organizações internacionais dispõem de força normativa para impor, sozinhas, dentro de cada território, sua vontade política e econômica. Com a globalização, aumentou-se a complexidade da relação entre território nacional e economia internacional, o plano interno e o externo; o território continua existindo, as normas públi- 
cas que o regem são nacionais, ainda que as forças mais ativas do seu dinamismo atual tenham origem externa (Bresser-Pereira, 2009; Fiori, 2007; Santos, 2007).

Outro aspecto a demonstrar a importância do nível nacional é o fato de que o exercício da cidadania ainda depende, em grande medida, da presença e da ação dos Estados. Nos séculos XIX e XX, as lutas das classes trabalhadoras pela conquista de direitos democráticos e sociais levaram a mudanças nas leis em jurisdições com limites espaciais bem definidos. Todavia, a tendência à globalização dos mercados e das finanças abriu as fronteiras dos Estados à crescente competição internacional. O processo de globalização reforçou a desmontagem dos mecanismos nacionais de proteção das vítimas da livre economia mundial. Nesse sentido, a atual debilidade dos Estados ameaça não apenas os direitos dos trabalhadores, mas todos os direitos democráticos. Assim, observa-se uma crescente incompatibilidade entre a anatomia geográfica da economia mundial e a base territorial necessária para o exercício dos direitos individuais, políticos e sociais (Agnew, 2005; Arrighi e Silver, 2001; Hobsbawm, 1995; Santos, 2007).

A dicotomia entre Estado e mercado é falsa e esconde mais do que revela. O laissez-faire, por exemplo, não foi algo natural, mas produto da ação deliberada do Estado. Do mesmo modo, o livre comércio não teria existido sem um intervencionismo contínuo, controlado e organizado de maneira centralizada. Ao contrário de abordagens reducionistas, Estados e mercados são complementares e não substitutos. $\mathrm{O}$ equilíbrio entre ambos depende da posição internacional e da trajetória histórica de cada país. Apesar de não ser o único ator relevante, o Estado nacional continua sendo o agente imprescindível da dinâmica do capitalismo global. A forma-Estado, portanto, parece não passível de supressão enquanto existir a formamercadoria. Por ser um órgão de concorrência, desaparecerá apenas quando essa for suprimida (Harvey, 2009; Liguori, 2007; Polanyi, 2000; Rodrik, 2011). 
Em síntese, esta seção pretendeu analisar de que maneira a histórica relação entre Estado e capitalismo possibilitou o surgimento do moderno sistema interestatal e viabilizou o processo de acumulação de capital. Foram analisadas as relações contraditórias entre a lógica territorial e a lógica do capital. Da mesma forma, foram abordadas as relações assimétricas e hierárquicas que caracterizam o sistema internacional. Ao longo da história, o Estado mostrou-se a entidade política mais capaz de orquestrar arranjos institucionais e manipular as forças moleculares de acumulação, a fim de preservar as assimetrias e as hierarquias do sistema internacional. Nesse sistema, vale a regra segundo a qual "quem não sobe, cai”. Todavia, para fugir da narrativa cíclica de ascensão e queda das grandes potências, que trata o hegemon sem analisar o caráter distintivo de sua hegemonia, faz-se necessária uma narrativa que investigue as características do atual país hegemônico, os Estados Unidos da América.

\subsection{A hegemonia dos Estados Unidos e a nova geografia do poder global}

Para entender a atual ordem internacional e sua geografia do poder, é preciso analisar a sociedade de consumo de massas e o modelo de produção norte-americano. A principal característica da política mundial contemporânea é resultado de uma hegemonia específica exercida tanto pelo governo dos Estados Unidos quanto por uma vasta gama de instituições, cujas estruturas e normas se baseiam na sociedade de mercado gestada nesse país nos séculos XIX e XX. Por esse prisma, a atual globalização deve ser vista como um projeto hegemônico intimamente conectado ao cálculo geopolítico e aos interesses econômicos norte-americanos.

Os Estados Unidos desenvolveram uma forma específica de imperialismo. Diferentemente da Europa, a ausência de um passado feudal permitiu a adoção de um novo modo de governo e tornou 
mais fácil racionalizar a produção e o trabalho. Combinando-se habilmente a força - repressão ao sindicalismo - com a persuasão - altos salários, benefícios e propaganda ideológica eficiente -, logrou-se basear toda a vida do país sobre a produção. Além disso, a posse abundante de espaço possibilitou que tanto a lógica do poder capitalista como a lógica do poder político pudessem dispor de significativa margem de manobra. Após se expandir para o Oeste, a teoria do destino manifesto contribuiu para os Estados Unidos formarem seu próprio gênero de racismo expansionista e idealismo internacional. Desde então, o país aprendeu gradualmente a mascarar o caráter explícito das conquistas e das ocupaçóes territoriais sob o disfarce de uma universalização não espacial de seus valores, secundada por uma retórica que acabaria por culminar no que depois veio a ser conhecido como globalização. Nesse sentido, os Estados Unidos buscaram ocultar sua ambição expansionista num universalismo abstrato, preferindo expressões como "século americano" a "império americano". Assim, a negação da geografia e a retórica da universalidade serviram para esconder, mais deles mesmos do que dos outros, suas ambições territoriais (Gramsci, 2008; Harvey, 2009).

Marx (2013) observou que, entre as principais consequências da Guerra Civil norte-americana (1860-65), se destacavam a rápida centralização do capital e o avanço da produção capitalista. Nas três décadas que se seguiram ao conflito, houve a aceleração da produção e do emprego industriais, o surgimento de grandes fábricas e o desaparecimento de estabelecimentos artesanais. Segundo Giovanni Arrighi e Beverly J. Silver (2001), quando o território foi varrido por uma onda de construção de ferrovias, quase todas financiadas pelos britânicos, as barreiras espaciais internas foram superadas, estabeleceu-se o acesso privilegiado dos Estados Unidos aos dois maiores oceanos e passou a haver uma complementação integral de capacidades produtivas excepcionais - não somente na indústria, mas também na agricultura. Formou-se, assim, um complexo 
industrial militar mais poderoso do que qualquer dos complexos análogos europeus.

A partir de 1870, o crescimento econômico dos Estados Unidos passou a ser alavancado por grandes indústrias e bancos de investimento. A primeira fase de concentração industrial coincidiu com o início da longa depressão de 1873. Nessa época, emergiram conglomerados financeiros e industriais, como o J.P. Morgan e a Standard Oil Company, de John D. Rockefeller. Diferentemente de outros países, onde o controle permaneceu familiar por mais tempo, os Estados Unidos foram pioneiros na separação entre a administração e a propriedade das empresas e no estímulo à venda de ações. A recuperação econômica do período 1896-1905 marcou a maior onda de fusões e aquisições da história norte-americana; maior, em termos reais, do que movimentos semelhantes que ocorreriam nos anos 1920, 1960 e 1980. Entre as firmas surgidas naquela época, destacam-se a General Electric, a Eastman Kodak e a U.S. Steel (Agnew, 2005).

Foi somente a partir de 1890, entretanto, que os líderes empresariais e governamentais norte-americanos se tornaram defensores de uma agressiva expansão no exterior. No plano militar, os Estados Unidos derrotaram a Espanha na guerra de 1898 e avançaram sobre a América Central e o Caribe. Aproveitaram o impulso e tomaram também as ilhas Guam, o Havaí, além das Filipinas (Moura, 1990). No plano econômico, o país preparou o terreno para a globalização da produção. Em 1914, pelo menos 41 empresas norte-americanas, sobretudo do setor de máquinas e de processamento alimentar, tinham construído duas ou mais fábricas no estrangeiro. Assim, a globalização da produção, que teria seu apogeu após 1945, tem suas raízes na concentração econômica e nos investimentos externos estadunidenses, ocorridos entre o final do século XIX e o início do XX (Agnew, 2005).

A expansão estadunidense não foi apenas resultado de forças econômicas, pois contou com decisões políticas importantes. Alguns 
críticos já chamaram os Estados Unidos de baluarte do protecionismo moderno. Com efeito, muitos assinalam que foi Alexander Hamilton, o primeiro secretário do tesouro norte-americano, e não Friedrich List, como normalmente se acredita, o primeiro a elaborar sistematicamente o argumento da indústria nascente. Entre fins do século XIX e 1920, graças ao protecionismo, a economia dos Estados Unidos foi a que mais cresceu no mundo (Chang, 2004).

O expansionismo teve também alicerces diplomático e cultural. No âmbito da política externa, era preciso tornar o mundo mais "seguro" para os investimentos das empresas norte-americanas. No plano cultural, as elites estadunidenses acreditavam possuir a missão de espalhar os "valores americanos". Afinal, o etos da produção e do consumo de massas havia sido uma invenção norte-americana. Todavia, o "sonho americano" e a democratização do desejo não podiam ficar confinados territorialmente. Era necessário reconfigurar a história da "fronteira" - até então difundida pela educação de massa, pelos meios de comunicação e pela cultura popular dos Estados Unidos - a fim de expandi-la. Dessa forma, segundo o geógrafo John Agnew (2005, p. 100),

'Americanism', the peculiar character of the American society and economy and the glue of consumer culture that increasingly bonded them together, therefore, has a number of distinctive roots in the American historical experience. But they came together to define a particular national culture that was more or less in place by the 1890 s and early 1900 s [...]. It has been the projection of this hegemony from home, so to speak, out into the world at large that has set the political basis for the globalization of the world economy over the past thirty or so years. ${ }^{7}$

7 O trecho correspondente na tradução é: “'Americanismo', o caráter peculiar da sociedade e da cultura norte-americana e o elo aglutinador da cultura consumista que crescentemente reúne essas características, portanto, possui distintas raízes na experiência histórica estadunidense. Mas esses elementos se juntaram para definir uma 
Alguns autores divergem sobre o conceito que melhor define a influência dos Estados Unidos no mundo. Para Michael Hardt e Antonio Negri (2012), tal influência deve ser chamada de império, a nova forma assumida pela soberania, que passou a se caracterizar por uma série de organismos nacionais e supranacionais unidos por uma lógica ou regra única. $\mathrm{O}$ conceito refere-se a um conjunto de práticas associadas à acumulação de capital e à exploração do trabalho, uma espécie de imperialismo sem imperador. A transição para o império teria surgido do crepúsculo da soberania moderna. Ao contrário do imperialismo, o império não estabelece um centro territorial de poder, nem se baseia em fronteiras ou barreiras fixas, mas trata-se de um aparelho de descentralização e desterritorialização que incorpora gradualmente o mundo inteiro dentro de suas fronteiras abertas e em expansão. Diferentemente do imperialismo, nenhum país ocupa a posição de liderança mundial que as potências europeias um dia ocuparam. O império é concebido como uma república universal, uma rede de poderes e contrapoderes estruturada em uma arquitetura ilimitada e inclusiva, que permitiria que as pessoas comuns - a "multidão" - se libertassem das reificações territoriais, como Estados e lugares.

$\mathrm{Na}$ estrutura concebida por Hardt e Negri (2012), os Estados Unidos ocupam uma posição privilegiada, pois sua tendência expansiva estaria inscrita em sua Constituição. De acordo com tal interpretação, Thomas Jefferson e os federalistas inspiraram-se no antigo modelo imperial e acreditavam estar criando do outro lado do Atlântico um novo império, com fronteiras abertas e em expansão, onde o poder seria distribuído em redes. Essa concepção imperial sobreviveu e amadureceu ao longo da história estadunidense, e surgiu agora em escala global, na sua forma plenamente desenvolvida.

cultura nacional específica que estava mais ou menos formada por volta de $1890 \mathrm{e}$ início dos 1900. Foi a projeção dessa hegemonia doméstica no mundo que lançou as bases políticas da globalização da economia mundial nos últimos trinta anos”. 
Ao contrário dos autores de Império, Agnew (2005) acredita que o conceito de "hegemonia" é o que melhor se aplica aos Estados Unidos. Para o geógrafo, a hegemonia pode ser exercida por meio da aceitação e do consentimento dos demais, sem necessidade de controle territorial. Além disso, embora os Estados continuem importantes, é preciso ampliar o conceito de geografia do poder: a ênfase em elementos territoriais deve ceder lugar a noções funcionais e relacionais de espacialidade, envolvendo o controle sobre as regras de interação de espaço, a exemplo do comércio e dos fluxos de capital. Assim, a geografia do poder contemporânea é considerada muito complexa para ser reduzida ao conceito de império.

O conceito de hegemonia foi desenvolvido por Gramsci a partir da imagem de poder de Maquiavel: um centauro, metade homem, metade animal, uma combinação necessária de consentimento e coerção. Apesar de o conceito compreender direção intelectual e dominação como elementos simultâneos, a hegemonia apenas prevalece enquanto o aspecto consensual do poder estiver em primeiro plano. Além disso, a hegemonia ideológica do dominante se enraíza na sua hegemonia econômica, da qual a direção intelectual e moral é função. Portanto, a função hegemônica possui dois aspectos: o econômico e o ético-político (Cox, 2007; Liguori, 2007).

Apesar do projeto hegemônico norte-americano dispensar a incorporação de territórios e ter um inegável componente cultural, os Estados Unidos agridem com frequência os países mais fracos. Segundo Fernando Henrique Cardoso (2010), os Estados Unidos veem-se como xerifes do mundo, conquanto não colonizem nem se disponham a permanecer no exercício de um controle político-administrativo nos países agredidos, o que poderia, eventualmente, assegurar maior êxito ao seu pretenso papel civilizatório. Já Daniel Bensaid (2008) afirma que a negação da relação de domínio imperial permite modificar os enunciados do conflito e reorganizar a visão do mundo em torno de uma oposição teológica entre o Bem (o Ocidente, as democracias, a civilização) e o Mal (as ditaduras; os 
rogue states). Cada vez mais, as intervenções militares têm sido justificadas como legítima defesa da civilização ameaçada. Desse modo, Bensaid argumenta que, em um mundo marcado por assimetrias de poder, as intervenções humanitárias mascaram os interesses de dominação imperial e justificam a ingerência do forte no fraco e a negação unilateral das soberanias democráticas.

A hegemonia norte-americana é baseada tanto em aspectos consensuais quanto coercitivos. É inegável a influência cultural estadunidense no mundo. Do mesmo modo, as mais de 700 bases militares e os cerca de $300 \mathrm{mil}$ soldados em, aproximadamente, 70 países indicam a importância do poder territorial para os Estados Unidos (Fiori, 2007, p. 126; Mészáros, 2003, p. 55). No entanto, em vez de discutir o peso de cada um dos elementos, é preciso investigar a raiz da hegemonia norte-americana. Hardt e Negri (2012) argumentam que a globalização contemporânea nasceu com base na expansão mundial do projeto constitucional interno dos Estados Unidos. O império seria a projeção da Constituição norte-americana, pois o projeto constitucional do país foi construído segundo o modelo de rearticulação de um espaço aberto e da reinvenção incessante de relações singulares e diversas em redes em um terreno ilimitado. Do mesmo modo, Arendt (1989) afirma que a forma de governo dos Estados Unidos seria a menos adequada para uma política de poder imperialista. Contrariando essa linha argumentativa, Agnew (2005) defende a tese de que a hegemonia norte-americana teria sua origem na expansão da sociedade de mercado criada pioneiramente naquele país.

A sociedade de mercado norte-americana ganhou impulso com o advento do regime de acumulação, ou sistema de produção, conhecido como fordismo. ${ }^{8}$ Henry Ford reconheceu que produção de massa

8 Deve-se esclarecer que os conceitos "regime de acumulação fordista" e "modo de regulação” foram estabelecidos pelos economistas da escola da regulação francesa. Segundo Robert Boyer (2009), um dos principais representantes dessa escola, o regime de acumulação intensivo, baseado na produção e no consumo de massa, é a principal característica do fordismo. Tal regime se caracteriza por um modo de 
significava consumo de massa e que, portanto, era necessário criar um novo sistema de reprodução da força de trabalho, uma nova política de controle e gerência do trabalho, uma estética e uma psicologia inovadoras, enfim, um novo tipo de homem e uma sociedade racionalizada e moderna (Harvey, 2013). Para Gramsci (2008), o americanismo surgiu como um modo de vida profundamente imbricado na esfera produtiva com o taylorismo - como modelo de organização do trabalho - e com o fordismo - como mecanismo de acumulação de capital. Nos Estados Unidos, o avanço da racionalização exigiu um novo tipo humano, compatível com os novos modelos de trabalho e processo produtivo. Esses métodos inovadores de trabalho eram indissolúveis de um determinado modo de viver, de pensar, de sentir a vida. Assim, o fordismo contribuiu para a criação de um novo tipo de trabalhador e de homem.

O fordismo foi acompanhado do aumento da intervenção estatal na economia, um fenômeno também identificado por Gramsci, que resultaria na política do New Deal. Uma vez consolidado internamente, os Estados Unidos passaram a exportar seu modelo econômico-cultural. Em seus primórdios, uma hegemonia mundial foi uma expansão da hegemonia interna de um país para o exterior. Dessa maneira, as instituições sociais e econômicas, a tecnologia e a cultura associadas a essa hegemonia nacional tornaram-se modelos a ser imitados no exterior. Posteriormente à crise de 1929 e à Segunda Guerra Mundial, o novo demiurgo, o capitalismo norte-americano, expandiu seu predomínio, enfatizando a característica central do sistema capitalista: a contínua modificação das técnicas produtivas e o entrelaçamento específico entre as ordens política, social e econômica (Cardoso, 2010; Cox, 2007).

regulação monopolista ou administrado, por ser organizado a partir da institucionalização dos procedimentos de ajuste em resposta aos riscos da atividade econômica. Durante a "era de ouro" do capitalismo (1947-1973), o modo de regulação dominante foi o keynesianismo, cujo sucesso dependia da arquitetura econômica internacional representada pelo sistema de Bretton Woods. 
$\mathrm{Na}$ esfera internacional, a hegemonia não é apenas uma ordem entre Estados. Trata-se, pois, de uma ordem no interior de uma economia mundial com um modo de produção dominante que penetra todos os países de diferentes formas. De acordo com Robert W. Cox (2007, p. 118-119), a hegemonia no âmbito internacional

É também um complexo de relações sociais internacionais que une as classes sociais de diversos países. A hegemonia mundial pode ser definida como uma estrutura social, uma estrutura econômica e uma estrutura política, e não pode ser apenas uma dessas estruturas: tem de ser todas as três ao mesmo tempo. Além disso, a hegemonia mundial se expressa em normas, instituições e mecanismos universais que estabelecem regras gerais de comportamento para os Estados e para as forças da sociedade civil que atuam além das fronteiras nacionais - regras que apoiam o modo de produção dominante.

$\mathrm{Na}$ segunda metade do século $\mathrm{XX}$, a expansão mundial do capitalismo, sob hegemonia norte-americana, mudou a divisão internacional do trabalho e o esquema centro-periferia proposto pela hegemonia inglesa. O espaço econômico internacional, finda a Segunda Guerra Mundial, foi construído a partir do projeto de integração entre as economias nacionais proposto pelo Estado norte-americano e por sua economia (Belluzzo, 2013). Da mesma forma que, como bem descreveu Karl Polanyi (2000), a economia de mercado, o livre comércio e o padrão ouro haviam sido inventos ingleses, as instituições internacionais consubstanciadas nos acordos de Bretton Woods foram projeções, em grande medida, das instituições e das práticas já desenvolvidas nos Estados Unidos.

A ordem econômica internacional do pós-guerra refletiu "a grande transformação" ocorrida nas relações entre Estado e sociedade, após o colapso do sistema liberal em 1929. Durante a chamada "era dourada" (1947-73), os Estados Unidos buscaram 
ativamente generalizar o contrato social do consumo de massas em todo o centro, promovendo o keynesianismo, o planejamento econômico, a integração econômica europeia e os movimentos sindicais não comunistas. Complementando o sistema de produção fordista, surgiu o modo de regulação keynesiano, que permitiu o advento do Estado de bem-estar social, ou Welfare State, nos países centrais. Além disso, os arranjos econômicos nacionais estavam relacionados com o "embedded liberalism" do sistema de Bretton Woods. Ao contrário do nacionalismo econômico dos anos 1930 e do liberalismo baseado no padrão ouro e no livre comércio, o compromisso do embedded liberalism era apoiado nos princípios do multilateralismo e da intervenção doméstica (Arrighi e Silver, 2001; Pedersen, 2008; Ruggie, 1982).

Os acordos de Bretton Woods reuniram 44 nações na cidade de New Hampshire em julho de 1944. O arranjo institucional resultou na criação do Banco Mundial, do Fundo Monetário Internacional (FMI) e do Acordo Geral sobre Tarifas e Comércio (GATT), que se converteria em Organização Mundial do Comércio (OMC), em 1994. Essas instituições deveriam evitar as flutuações do ciclo econômico por meio da "repressão financeira" e da abertura comercial moderada. Para isso, foram estabelecidos dois pilares para o novo sistema: taxas de câmbio fixas, mas ajustáveis, e controle dos fluxos de capitais. Promoveu-se, assim, a substituição da regulamentação privada pela regulação pública das altas finanças, deslocando o poder regulatório de Londres e Wall Street para Washington (Arrighi e Silver, 2001; Rodrik, 2011).

Segundo Luiz Gonzaga Belluzzo (2013), sob a égide de Bretton Woods, o poder do dólar conversível ${ }^{9}$ sustentou três processos simultâ-

\footnotetext{
9 John Maynard Keynes, delegado do governo britânico em Bretton Woods, rejeitou qualquer papel central para o dólar. Nesse sentido, propôs a Clearing Union, uma espécie de Banco Central dos bancos centrais. A Clearing Union emitiria uma moeda bancária, o bancor, destinada exclusivamente a liquidar posições junto aos bancos centrais. Os negócios privados seriam realizados nas moedas nacionais que,
} 
neos: a) o déficit na conta de capitais, produto da expansão da grande empresa estadunidense, garantiu o fluxo de liquidez requerida para o crescimento econômico mundial; b) daí, a reconstrução dos sistemas industriais da Europa e do Japão; e c) a industrialização fordista da periferia, alavancada pelo investimento produtivo direto em conjugação com políticas de desenvolvimento nacional.

O compromisso do embedded liberalism permitiu que os diferentes Estados desenvolvessem efetivos mecanismos de intervenção na economia doméstica com o propósito de afetar o nível de preços e de emprego, protegendo-os das flutuações externas. Assim, governos nacionais de tendências ideológicas distintas - gaullistas na França, trabalhistas na Inglaterra, ou democrata-cristãos na Alemanha Ocidental - criaram tanto um crescimento estável como um aumento dos padrões materiais de vida por meio de uma combinação de administração econômica keynesiana e políticas de bem-estar social. O conjunto dessas políticas ficou conhecido como "consenso keynesiano" (Harvey, 2013; Ruggie, 1982).

Todavia, a ordem de Bretton Woods e suas instituições nunca foram totalmente aplicadas aos países em desenvolvimento. $\mathrm{O}$ apelo hegemônico dos Estados Unidos ao Terceiro Mundo teve como pilares gêmeos a descolonização e o desenvolvimento. Em discurso na Assembleia Geral das Nações Unidas, o presidente John Kennedy propôs que a década de 1960 fosse designada pela ONU como "década do desenvolvimento". A teoria da modernização prometia que todos os povos do mundo poderiam realizar o "sonho americano". No entanto, o fordismo jamais foi hegemônico na região. No lugar do Welfare State, o subcontinente teve o "Estado desenvolvimen-

por sua vez, estariam referidas ao bancor, mediante um sistema de taxas de câmbio fixas, mas ajustáveis. No entanto, Harry D. White, representante do governo norte-americano, e sua equipe tiveram total controle sobre as regras e a redação dos documentos oficiais. Assim, a imposição do dólar como moeda de reserva internacional e o caráter das novas organizações refletiram apenas uma situação de facto (Belluzzo, 2013; Ruggie, 1982). 
tista”, responsável pela política de "industrialização por substituição de importações” (ISI) proposta pela CEPAL. Apesar do êxito relativo, verificado sobretudo no Brasil e no México, a industrialização periférica não impediu o aumento da pobreza urbana e das desigualdades. Ademais, o elevado padrão de consumo das elites e a má distribuição de renda, além da imutabilidade da questão agrária, limitavam o aproveitamento da capacidade industrial já instalada (Arrighi e Silver, 2001; Domingues, 2009; Ruggie, 1982).

A primeira rodada de industrialização fordista na periferia merece algumas observações. Segundo Alice Amsden (2009), a ascensão daquilo que ela denominou de "resto", ou seja, os países não pertencentes ao Atlântico Norte, foi uma das transformações mais fenomenais da segunda metade do século XX. Pela primeira vez na história, os países "atrasados" ou subdesenvolvidos se industrializaram sem inovações próprias. Eles lograram avançar em setores industriais que exigiam um elevado grau de capacidades tecnológicas sem terem inicialmente nenhuma capacidade tecnológica avançada. Por ser um caso de aprendizado puro, a industrialização tardia significou uma completa dependência inicial da tecnologia comercializada por países já desenvolvidos. Essa dependência emprestou ao processo suas características peculiares.

A industrialização periférica foi forçada a realizar-se num período relativamente curto, o que significava implantar um complexo de atividades produtivas que, em outras partes, se formara no curso de várias gerações. Como as fontes de tecnologia estavam no exterior e o acesso a elas, em muitos casos, era restrito, foi necessário algum tipo de cooperação internacional, que ocorreu por meio da instalação nos países latino-americanos de filiais das empresas que anteriormente abasteciam o mercado, cabendo a elas uma parcela crescente nas atividades produtivas. Dessa maneira, quanto mais tarde um país se industrializava, maior a probabilidade de que suas grandes empresas manufatureiras fossem de propriedade estrangeira (Amsden, 2009; Furtado, 2007). 
Os processos de catching up ou "alcançamento" tiveram características diferentes a depender do país e da região. Alguns países asiáticos, como China, Coreia do Sul e Taiwan, investiram pesado em habilidades nacionais próprias, o que os ajudou a sustentar a propriedade nacional de empresas nas indústrias de média tecnologia e a avançar em setores de alta tecnologia com base em "líderes nacionais". Devido à Guerra Fria, esses países contaram também com um "bônus geopolítico", que garantiu maior grau de autonomia na condução das respectivas estratégias nacionais. Em contraste, a Argentina, o México e, em menor medida, o Brasil aumentaram sua dependência do know- how estrangeiro para o crescimento futuro. Na verdade, a geração de tecnologia esteve, muitas vezes, ausente desde o início do desenvolvimento capitalista na América Latina. Os níveis de investimento estatal e, particularmente, privados em Ciência e Tecnologia (C\&T) e Pesquisa e Desenvolvimento (P\&D) foram consistentemente muito baixos, ao contrário do que acontecia nos Estados Unidos, na Europa e no Leste Asiático. As firmas transnacionais amiúde transplantavam para o subcontinente unidades e produtos defasados e raramente investiam localmente em P\&D. Além disso, as tecnologias instaladas, em geral, não se derramavam para a economia como um todo, o que contribuía para uma persistente heterogeneidade do tecido social (Amsden, 2009; Domingues, 2009).

Ao comparar a América Latina com o Leste Asiático, Prebisch verificava que suas estratégias de industrialização por substituição de importações eram semelhantes, mas, ao contrário dos latino-americanos, os asiáticos estavam criando indústrias globalmente competitivas. Já em 1961, a CEPAL advertira sobre a distorção que ocorria nas economias latino-americanas com suas indústrias superprotegidas e incapazes de exportar. $\mathrm{Na}$ Conferência das Nações Unidas sobre Comércio e Desenvolvimento (UNCTAD), por exemplo, Prebisch tinha visto a Coreia do Sul aplicar a doutrina cepalina com muito mais sucesso do que os países latino-americanos. A nação asiática tinha sido capaz de ter êxito tanto na produção 
para o mercado interno quanto naquela voltada para as exportações. Ademais, o economista argentino acreditava que a principal diferença em relação à América Latina não era a doutrina, mas a política governamental. A elaboração de políticas na Coreia do Sul refletia sua estrutura social mais equitativa, com um sistema de educação universal e uma reforma agrária bem-sucedida (Dosman, 2011).

Entre 1930 e 1980, o Brasil adotou uma política de industrialização baseada no desenvolvimentismo, nome dado à sua estratégia nacional de desenvolvimento e à sua ideologia condutora. Nesse período, o país atingiu elevadas taxas de crescimento econômico e criou capacidades estatais importantes para fomentar o desenvolvimento. $\mathrm{O}$ avanço da industrialização foi baseado em um mercado urbano restrito, mas relevante em termos de renda gerada, permitindo o advento de uma indústria moderna. Se o processo industrializante intensificou o caráter social excludente, nem por isso deixou de se converter em uma possibilidade de desenvolvimento e de transformação da estrutura produtiva para níveis de complexidade crescente. Nessa direção, o II Plano Nacional de Desenvolvimento (PND) foi bem-sucedido do ponto de vista estritamente econômico, pois completou a matriz interindustrial brasileira e mudou, de forma substantiva, os resultados da balança comercial e o perfil de nossa pauta de exportações e importações (Bresser-Pereira, 2009; Cardoso e Faletto, 2011; Paulani, 2010).

Os esforços da CEPAL e da UNCTAD, que foram apoiados pela política externa brasileira, lograram colocar o diálogo Norte-Sul no centro das discussões internacionais nas décadas de 1960 e 1970. Em 1968, a II UNCTAD propôs reformar o sistema econômico internacional. A ideia de um Sistema Geral de Preferências (SGP) seria aprovada no ano seguinte com base nos seguintes princípios: generalidade; não reciprocidade e não discriminação. O SPG visava a impulsionar as manufaturas e semimanufaturas dos países subdesenvolvidos, facilitando seu acesso aos mercados dos países desenvolvidos. O reformismo dos países do Terceiro Mundo culminaria na 
aprovação, pela Assembleia Geral das Nações Unidas, da "Declaração e programa de ação da nova ordem econômica internacional”, em 1974. Trata-se de uma época na qual os planos de reformas da ordem internacional eram inspirados por princípios éticos (Dosman, 2011; Fonseca Jr., 2004; Furtado, 2007).

Entre 1947 e 1995, as oito rodadas de liberalização do GATT eliminaram parte das restrições à importação existentes desde a década de 1930 e reduziram as elevadas tarifas do pós-guerra. Assim, o volume do comércio mundial cresceu a uma taxa anual média de $7 \%$ entre 1948 e 1990, a maior já registrada. As regras do GATT permitiram também que os países em desenvolvimento perseguissem suas próprias estratégias de desenvolvimento com poucas limitações externas; a agricultura e parte do setor de serviços não entraram na agenda de liberalização. Ademais, os países em desenvolvimento podiam recorrer a cláusulas que lhes possibilitavam impor limitações às importações de modo permanente (Rodrik, 2011). No entanto, a onda reformista que vinha crescendo desde o pós-guerra chegaria ao fim com a virada neoliberal, simbolizada pelas vitórias eleitorais de Margareth Thatcher, na Inglaterra, e de Ronald Reagan, nos Estados Unidos.

O sucesso do regime de Bretton Woods continha as sementes de sua própria debilidade. Os cuidados típicos da era keynesiana estavam voltados, sobretudo, para mitigar a instabilidade dos mercados de negociação de títulos representativos de direitos sobre a riqueza e a renda. As políticas monetárias e de crédito se ocupavam em atenuar os efeitos da valorização fictícia da riqueza sobre as decisões de gasto corrente e de investimento da classe capitalista. Desse modo, almejava-se evitar ciclos de valorização excessiva e desvalorizações catastróficas dos estoques de riqueza. Segundo Belluzzo (2013), ironicamente, as políticas keynesianas anticíclicas cumpriram o que prometeram ao evitar as recorrentes crises de desvalorização de ativos, mas, ao garantir o valor dos estoques de riqueza existentes, ampliaram seu peso na composição da riqueza total e ampliaram os poderes de "coordenação" das instituições financeiras. 
Desde os anos 1960, foi ficando cada vez mais evidente a incapacidade do fordismo e do keynesianismo de conter as contradições inerentes ao capitalismo. A formação do mercado de eurodólar ${ }^{10}$ e a contração do crédito no período $1966-67$ foram sinais prescientes da incapacidade norte-americana de seguir regulando o sistema financeiro internacional. Os Estados Unidos enfrentavam dificuldades em financiar a Guerra do Vietnã e crescentes desequilíbrios no seu balanço de pagamentos. Em 1971, confrontado com a frequente demanda de outros países para converter seus dólares em ouro, Richard Nixon suspendeu a conversibilidade do dólar em ouro a uma taxa fixa. Dois anos depois, em 1973, a adoção de um sistema de taxa de câmbio flexível marcou a completa abolição do compromisso de Bretton Woods. De maneira irônica, o impulso à globalização que se seguiu a essas decisões unilaterais foi baseado explicitamente na busca do interesse econômico nacional dos Estados Unidos (Agnew, 2005; Harvey, 2013; Rodrik, 2011).

$\mathrm{Na}$ década de 1970, a transição de um regime favorável ao trabalho para outro hostil aos trabalhadores não se deveu à debilitação do Estado, mas ao enfraquecimento estrutural da própria classe trabalhadora com o advento da "sociedade pós-industrial" (Arrighi e Silver, 2001). Como lembra John Ruggie (1982), o ressurgimento do etos do capitalismo liberal resultou da erosão do equilíbrio que até então existia nas relações entre Estado e sociedade. A profunda recessão de 1973 colocou em movimento uma série de processos que solaparam o compromisso fordista, levando a transformações

${ }^{10}$ Em 1958, permitiu-se a criação de uma offshore na cidade de Londres, ou seja, de um mercado interbancário de capitais líquidos registrados em dólares, conhecido como "mercado de eurodólares". Grandes empresas ajudaram a sua formação, juntamente com muitos bancos que aproveitaram para começar a se internacionalizar. Antes mesmo do "choque do petróleo", os lucros não repatriados ou não investidos na produção eram depositados em eurodólares pelas firmas transnacionais norte-americanas. Essas transações eram feitas sem qualquer regulação estatal. À medida que o dinamismo da "idade de ouro" se esgotava, o afluxo de recursos não investidos se acelerava (Chesnais, 2005). 
tanto na natureza do processo de produção quanto na estrutura de regulação nacional e internacional. Começou, então, a tomar forma um conjunto de novas experiências nos domínios da organização industrial e da vida social e política. Essas mudanças provocaram a passagem para um regime de acumulação inteiramente novo, conhecido como acumulação flexível (Harvey, 2013; Pedersen, 2008).

Ao contrário do fordismo, a acumulação flexível se apoiava na flexibilidade dos processos de trabalho, dos mercados laborais e dos produtos e padrões de consumo. Envolvia também um novo movimento de compressão do espaço-tempo no mundo, resultado do estreitamento dos horizontes temporais de tomada de decisão, devido aos avanços tecnológicos e à queda vertiginosa dos custos de transporte. Esses fatores combinados possibilitaram progressivamente a difusão imediata das decisões em um espaço cada vez mais amplo e variegado (Harvey, 2013). As tecnologias de informação revolucionaram, ao mesmo tempo, as técnicas produtivas, as formas organizacionais das entidades públicas e privadas e o sistema de comando, tanto dentro das empresas como na sociedade. Por mais que a robotização e as técnicas microeletrônicas tenham transformado os sistemas produtivos e impulsionado o processo de acumulação, foram as novas técnicas de informação e sua disponibilidade prática que permitiram a incorporação desses avanços à vida cotidiana. Além disso, essas tecnologias deram margem à multiplicação dos fluxos de capital e à criação de novos "produtos financeiros" (bedge funds, derivativos, mercados futuros), todos difundidos pelas redes globais de comunicação e pela internet (Cardoso, 2010).

O novo regime de acumulação rompeu a correlação geográfica que havia entre produção e consumo no fordismo clássico, territorial por natureza. Embora muitos produtos continuem sendo produzidos em massa, a produção ocorre em diferentes regiões (fenômeno da deslocalização), criando uma cisão entre produtores e consumidores. Com isso, o trabalho organizado foi solapado pela reconstrução de focos de acumulação flexível, em regiões periféricas que careciam de tradição industrial, e pela reimportação para os centros das nor- 
mas e práticas regressivas estabelecidas nessas novas áreas. Assim, a acumulação flexível significou níveis altos de desemprego estrutural, rápida destruição e reconstrução de habilidades, elevação modesta dos salários reais e retrocesso do poder sindical - uma das vigas políticas do regime fordista. Apesar dessa "grande transformação" às avessas, quando a economia tratou de se libertar dos grilhões da sociedade, o apelo mundial da sociedade de mercado se manteve, sugerindo que o americanismo dependia menos da fábrica e mais da ideologia, numa proporção que nem Gramsci poderia imaginar (Agnew, 2005; Belluzzo, 2013; Harvey, 2013).

As transformações no regime de acumulação tiveram impacto no equilíbrio entre o poder do Estado e o poder das finanças, com o fortalecimento do sistema financeiro. Nos trinta anos que se seguiram ao colapso de Bretton Woods, os Estados Unidos promoveram as políticas de abertura comercial e impuseram a liberalização urbi et orbi. A implementação da liberalização financeira apoiou-se em três elementos inter-relacionados: a desregulamentação, a desintermediação e a descompartimentalização interna e externa. A desregulamentação significou a liberalização monetária e financeira. A desintermediação permitiu às instituições financeiras não bancárias - como os investidores institucionais - terem acesso aos mercados como emprestadoras. Por sua vez, a descompartimentalização interna abriu caminho para uma (des)especialização progressiva dos bancos em nome da concorrência e da liberdade de empreendimento; já a descompartimentalização externa promoveu sucessivamente a liberalização dos mercados de câmbio, a abertura do mercado de títulos públicos aos operadores estrangeiros e a abertura das Bolsas às empresas estrangeiras. Assim, a conjunção desses três elementos contribuiu para a formação de um mercado de ações global, mercados futuros de mercadorias e dívidas globais, além de acordos de compensação recíproca de taxas de juros e moedas. Tais mudanças, somadas à acelerada mobilidade geográfica de capitais, permitiram a criação, 
pela primeira vez, de um único mercado mundial de dinheiro e de crédito (Belluzzo, 2013; Chesnais, 2005; Harvey, 2013).

A associação entre liberalização das contas de capital e desregulamentação financeira provocou a formação de bolhas nos mercados de ativos e a sucessão de crises bancárias, cambiais e de endividamento soberano. De acordo com Dani Rodrik (2011, p. 109), entre 1970 e 2008, ocorreram 124 crises bancárias, 208 crises cambiais e 63 crises de dívida soberana. A abertura das contas de capital suscitou a disseminação dos regimes de taxas de câmbio flutuantes que ampliaram o papel de "ativos financeiros" das moedas nacionais. Segundo Belluzzo (2013), as flutuações das moedas criaram oportunidades de arbitragem e de especulação ao capital financeiro internacionalizado e tornaram as políticas monetárias e fiscais domésticas reféns da volatilidade das taxas de juros e de câmbio.

Ao aumentar a fluidez dos espaços de circulação da riqueza e da renda dos grupos integrados, a globalização financeira desarticulou a velha base tributária das políticas keynesianas, impondo limites aos gastos sociais dos governos, vistos como inflacionários. Nos Estados Unidos da era Reagan, entraram em voga a "economia da oferta" e a Curva de Laffer, que preconizavam a redução de impostos para os ricos e para as empresas. A supply side economics defendia a tese do "gotejamento" (trickle down), segundo a qual as classes trabalhadoras e os governos receberiam os benefícios da riqueza acumulada livremente pelos abonados empreendedores sob a forma de salários crescentes e aumento das receitas fiscais. No entanto, a migração da grande empresa para as regiões de baixos salários, a desregulamentação financeira e o enfraquecimento sindical desmentiram as hipóteses do trickle down. Nesse período, ao contrário do que se difunde, o Estado nacional não se tornou menor, mas se omitiu quanto ao interesse das populações e se tornou mais forte a serviço dos interesses econômicos dominantes. Assim, o Estado não saiu de cena, apenas mudou de agenda (Agnew, 2005; Belluzzo, 2013; Santos, 2007). 
As organizações internacionais criadas em Bretton Woods - o FMI e o Banco Mundial - foram reformuladas e passaram a impor, a partir da crise da dívida externa dos anos 1980, programas de ajuste estrutural aos países periféricos, que envolviam mudanças não só das políticas econômicas internas, como das estruturas institucionais domésticas. Nesse sentido, essas duas organizações agiram como canais transmissores das ideias neoliberais, reforçando em muitos casos as reformas pró-mercado que estavam em curso e que reduziam ainda mais a autonomia dos Estados situados na periferia do sistema internacional. Até a crise do subprime $e^{11}$ de 2008, o FMI e o Tesouro norte-americano continuaram a propor a liberalização das contas de capital e a incentivar os países a remover os impedimentos à finança internacional. Em tese, o receituário dessas instituições pretendia atacar manifestações da pobreza, mas estruturalmente contribuiu para aprofundar a desigualdade e a exclusão social (Hurrell, 2009; Krasner, 2001; Rodrik, 2011; Santos, 2007).

No âmbito da política comercial, passou-se de um regime que regulava o movimento entre fronteiras de bens para outro cujas disciplinas tinham como objeto as políticas domésticas dos países-membros. Na Rodada Uruguai (1986-94), os Estados Unidos conseguiram incorporar três novos temas - serviços, propriedade

${ }^{11}$ Iniciada em 2007 e acelerada pela quebra do Lehman Brothers em setembro de 2008, a crise permitiu avançar na compreensão das mudanças ocorridas nas relações entre inovaçôes financeiras, financiamento dos gastos de consumo das famílias, de investimento das empresas e geração de renda e emprego na economia globalizada. A aventura do crédito hipotecário generalizou para a massa de consumidores o "efeito-riqueza". Esse novo momento de "inflação de ativos" estava assentado em três fatores determinantes: 1) a degradação dos critérios de avaliação de risco de crédito e o "aperfeiçoamento" dos métodos de captura dos devedores primários, as famílias de renda média e baixa, cuja capacidade de pagamento estava debilitada pela estagnação dos rendimentos nos últimos trinta anos; 2) o alargamento do espaço da securitização das hipotecas, mediante a criação e multiplicação de ativos lastreados nas dívidas das famílias; e 3) a possibilidade de "extrair" novos empréstimos apoiados na valorização dos imóveis e destinados à aquisição de bens duráveis, passagens aéreas e até pagamento de impostos. Assim, as técnicas de securitização dos créditos bancários e de distribuição de riscos, o uso de derivativos e a intensa informatização dos mercados ampliaram o volume de transações e estimularam a "alavancagem" imprudente (Belluzzo, 2013). 
intelectual e medidas de investimento -, que posteriormente se tornariam: o Acordo sobre o Comércio de Serviço (GATS); o Acordo sobre Aspectos dos Direitos de Propriedade Intelectual Relacionados ao Comércio (TRIPS); e o Acordo sobre Medidas de Investimento Relacionadas ao Comércio (TRIMS). Os governos do Brasil e da Índia resistiram sem sucesso à incorporação desses temas. Além da ampliação da pauta, o governo estadunidense denunciou sistematicamente um dos princípios inscritos desde o início, ainda que em posição secundária, nos estatutos do GATT: o princípio do desenvolvimento, que se traduziu, de forma original, no reconhecimento do conceito de "indústria nascente" e, mais tarde, na consagração do direito a tratamento especial e diferenciado dos países pobres, com a reforma do texto do Acordo Geral, operada em 1965 - incorporação do Capítulo IV relativo a Comércio e Desenvolvimento. Com a hegemonia neoliberal dos anos 1980 e 1990, a ideia de desenvolvimento tornou-se alvo de um ataque sistemático pelos países centrais e pelas instituições financeiras internacionais (Bresser-Pereira, 2009; Cruz, 2007).

A OMC restringiu a capacidade dos países em desenvolvimento de colocar em prática políticas industrial, comercial e tecnológica ativistas. Novas regras sobre patentes e propriedade intelectual obrigaram os países em desenvolvimento a criar leis em conformidade com as existentes nos países centrais. As regras sobre saúde pública também foram objeto do escrutínio da OMC. Ademais, esses governos foram proibidos de requerer às firmas transnacionais o uso de conteúdo local ou de limitar suas importações em relação a suas exportações, tornando ilegal muitas práticas que os próprios países desenvolvidos haviam usado no passado. Diante do novo cenário, os países em desenvolvimento passaram a enfrentar alguns desafios. De um lado, precisavam influenciar a elaboração das regras do jogo, a fim de deixar de serem "globalization takers" para se tornarem "globalization makers"; de outro, deviam evitar que as novas regras limitassem as perspectivas de desenvolvimento nacional. Para superar esses 
desafios, os países em desenvolvimento necessitavam aperfeiçoar sua capacidade de negociação internacional, além de serem capazes de criar foros e coalizões de geometria variável (Bresser-Pereira, 2009; Chang, 2004; Pedersen, 2008; Rodrik, 2011).

Uma comparação entre o período de Bretton Woods e o da hegemonia neoliberal demonstra que o desempenho da economia mundial foi superior durante a vigência do consenso keynesiano, já que esta cresceu a uma taxa per capita de 3\% ao ano entre 1950 e 1973, aproximadamente o dobro do índice verificado nos anos 1980 e 1990. Diante dessa evidência empírica, Rodrik (2011, p. 110) conclui que "the world economy simply has not performed as well during the era of financial globalization as it did under Bretton Woods". ${ }^{12}$ As únicas exceções foram a China e alguns países do sudeste asiático, como Taiwan e Coreia do Sul, que seguiram no jogo da globalização pelas regras de Bretton Woods, e não adotaram passivamente as regras liberalizantes hegemônicas. Dados do Banco Mundial confirmam as afirmações de Rodrik, como pode ser constatado na tabela 1.

Tabela 1 - Taxa de crescimento do PIB no mundo, na América do Norte, na América Latina e Caribe, na Europa Ocidental, no Leste Asiático e na China

\begin{tabular}{lllll}
\hline Regiáo & $\mathbf{1 9 6 0}$ & $\mathbf{1 9 7 0}$ & $\mathbf{1 9 8 0}$ & $\mathbf{1 9 9 0}$ \\
\hline América do Norte & 4,25 & 3,59 & 3,13 & 3,18 \\
América Latina e Caribe & 5,05 & 6,06 & 2,13 & 2,89 \\
Europa Ocidental & 4,50 & 3,51 & 2,29 & 2,16 \\
Leste Asiático & 7,91 & 4,66 & 5,01 & 3,45 \\
China & 2,71 & 7,44 & 9,75 & 9,99 \\
Mundo & 4,94 & 3,96 & 3,06 & 2,66 \\
\hline
\end{tabular}

Fonte: Banco Mundial, 2014.

${ }^{12} \mathrm{O}$ trecho correspondente na tradução é: "a economia mundial simplesmente não se desempenhou tão bem na era da globalização financeira como ocorreu no período de Bretton Woods". 
$\mathrm{O}$ acontecimento geopolítico e geoeconômico mais significativo do século XXI é a ascensão da China como o centro mais dinâmico dos processos de acumulação de capital. A China e o Leste Asiático tornaram-se a grande área manufatureira do mundo, mudando a relação centro-periferia, visto que os termos de troca no comércio internacional deixaram de inclinar-se a favor das manufaturas e contra os produtos primários. Na verdade, o bloco industrializado da Ásia funciona como uma engrenagem de transmissão entre a demanda gerada nos países centrais e a oferta das economias primário-exportadoras. Nesse sentido, há uma relação simbiótica entre o modelo asiático e as transformações financeiras e organizacionais que deram origem às novas formas de concorrência entre as empresas da tríade desenvolvida - Estados Unidos, Europa e Japão. O novo motor geoeconômico do capitalismo mundial deslocou e esvaziou o tripé da "época de ouro", que havia funcionado de maneira virtuosa entre 1945 e 1990 . O atual padrão de concorrência engendrou um duplo processo de centralização do controle (fusões e aquisições) e descentralização da produção, fenômeno presente nas estratégias de deslocalização dos investimentos. No plano geopolítico, a nova relação entre os Estados Unidos e a China é complementar e competitiva a um só tempo, além de ser simultaneamente econômica e militar (Belluzzo, 2013; Fiori, 2007).

Desde a Segunda Guerra Mundial, os Estados Unidos utilizaram elementos normativos e materiais para estabelecer regras, normas e instituições capazes de difundir a ideologia liberal, socializando os demais atores nos valores Ocidentais. Recentemente, alguns autores têm observado que a ascensão de países, como China, Índia, Brasil, Rússia e África do Sul, pode contribuir para o desenho de uma ordem mundial mais híbrida. Na medida em que adotam variedades de capitalismo com maior participação estatal, esses países podem tornar as instituições internacionais menos liberais. Apesar de não 
formarem um bloco monolítico, os países que pertencem ao BRICS ${ }^{13}$ têm uma causa comum, que é a adoção de estratégias que permitam a aceleração de seus respectivos processos de desenvolvimento. No entanto, o equilíbrio de poder mundial continua pendendo a favor dos antigos polos, cujo centro ainda é os Estados Unidos (Park, 2014; Stephen, 2014; Subacchi, 2008; Terhalle, 2011).

No âmbito regional, o fim da Guerra Fria, a crise do neoliberalismo e o unilateralismo da política externa norte-americana após 2001 possibilitaram o surgimento de projetos políticos mais autônomos na América do Sul. A ascensão de coalizões políticas nacionalistas ou de centro-esquerda permitiu a adoção de políticas externas mais autônomas. No Brasil, o governo Lula (2003-10) transformou o projeto de integração sul-americano em uma prioridade da política externa brasileira. Além de fortalecer e ampliar o Mercosul, o governo brasileiro foi um dos principais responsáveis pela criação da Unasul.

Diferentemente dos esquemas integrativos anteriores, a Unasul foi constituída para ser um foro de articulação, baseado em uma concepção ampliada que incorpora simultaneamente as dimensões política, econômica, social, cultural, ambiental, energética e de infraestrutura, conforme inscrito no preâmbulo do seu Tratado Constitutivo (Unasul, 2008). O fato de destacar a dimensão política revela que o escopo da organização não é somente econômico, mas sobretudo estratégico, e tende a permitir uma inserção mais autônoma dos países sul-americanos no mundo. Nesse sentido, o novo organismo pode contribuir para a transformação da América do Sul em um novo polo do sistema internacional.

${ }^{13}$ Em 2001, Jim O’ Neil, economista-chefe da Goldman Sachs, cunhou o acrônimo BRICS para referir-se às quatro grandes economias continentais que cresciam rapidamente. Em 2006, o conceito deu origem a um agrupamento, incorporado às políticas externas de Brasil, China, Índia e Rússia. Em 2011, por ocasião da III Cúpula, a África do Sul juntou-se ao grupo. 
A globalização, forma contemporânea da expansão capitalista, tem contribuído para difundir mundialmente o modelo de consumo de massas que ocorreu originalmente nos Estados Unidos. O fim da União Soviética e do bloco socialista levou ao colapso da mais importante oposição ideológica à ideia de sociedade de mercado em escala mundial. Desde então, mesmo países como China e Rússia, outrora relevantes economias centralmente planificadas, vêm adotando, cada um a seu modo, o modelo de consumo norte-americano. Assim, a globalização não se limita a um processo tecnológico ou econômico, porquanto possui raízes geopolíticas e tem contribuído para mudanças significativas da geografia do poder global.

Em resumo, as transformações estruturais da ordem mundial estão relacionadas a mudanças indispensáveis nas relações sociais e nas ordens políticas nacionais. Para entender a natureza da hegemonia norte-americana, é preciso analisar as especificidades da formação política, social, e econômica dos Estados Unidos, com destaque para o modelo de sociedade de mercado que teve origem naquele país. Além disso, mudanças nas relações do Estado com a sociedade significaram a passagem de uma ordem internacional baseada no consenso keynesiano para outra mais liberal. Essas transformações nas esferas doméstica e internacional tiveram características distintas nos países centrais e nos países periféricos. No início do século XXI, observam-se desafios à ordem hegemônica por parte de algumas nações em desenvolvimento, que passaram a adotar políticas externas mais autônomas. Nesse sentido, deve-se analisar o papel da política externa brasileira na construção de espaços regionais que apontem para a ampliação da autonomia do país e da América do Sul no sistema internacional. 


\subsection{Unasul: autonomia regional e expansão do capitalismo brasileiro}

A Unasul representa a vertente política da integração regional, constituindo-se num espaço de articulação que incorpora novas dimensões além da esfera comercial. Formada com o apoio decisivo dos governos de Brasil e Venezuela, a Unasul projeta geopoliticamente a América do Sul e contribui para uma inserção autônoma da região perante os Estados Unidos. Apesar de ter surgido num contexto de ascensão de governos progressistas, a formação do novo organismo coincidiu com a expansão das empresas brasileiras no subcontinente. Esse processo aponta para uma possível tensão entre a dimensão política e econômica da integração sul-americana.

A análise de política externa na América Latina costuma incorporar abordagens teóricas de outros lugares, mas com o cuidado de adaptá-las aos temas de interesse da região, a exemplo das questôes relativas à autonomia, ao desenvolvimento e ao papel do Estado. Assim, na produção acadêmica latino-americana, autonomia é um conceito que se refere a uma política externa livre dos constrangimentos impostos pelos países poderosos. Difere, portanto, do entendimento da maior parte dos autores do mainstream das Relações Internacionais, que define autonomia como o reconhecimento jurídico de Estados soberanos considerados “unidades iguais" em um sistema internacional anárquico (Giacalone, 2012; Vigevani e Cepaluni, 2011).

Para evitar confusão entre as noções de soberania e de autonomia, Roberto Russel e Juan Tokatlian (2003) sugerem que a primeira seja utilizada na esfera legal, deixando a segunda para a esfera pública. Dessa forma, o conceito de soberania se aproxima mais de uma concepção vestfaliana, evocando a imagem legal do princípio da não intervenção em assuntos internos de outros Estados. Já a noção de autonomia merece um tratamento mais estrito, significando condição e interesse nacional objetivo. Este, todavia, não deve 
ser visto como algo imutável, pois mudanças no ambiente interno podem levar os Estados a definirem seus objetivos de autonomia de maneira diferente.

A polissemia da noção de autonomia é consequência da diversidade de abordagens teóricas utilizadas para caracterizá-la, além das diferentes circunstâncias temporais e espaciais nas quais seu significado, seu escopo e sua importância são considerados. Apesar dessas divergências, há consenso quanto a considerar a autonomia como um conceito essencialmente político (Russel e Tokatlian, 2003). Se do ponto de vista dos países centrais a autonomia externa não é uma preocupação relevante, para os países periféricos o conceito é importante e possui uma dupla dimensão. Das fronteiras nacionais para dentro, a autonomia constitui um símbolo básico do Estado, um meio de assegurar formas distintas de desenvolvimento não dependente. Das fronteiras nacionais para fora, a autonomia é uma condição que possibilita os Estados formularem e implementarem sua política externa independentemente de constrangimentos impostos por países mais poderosos (Vigevani e Cepaluni, 2011).

Ao analisar o conceito de autonomia no âmbito regional, Russel e Tokatlian (2003) observam que este foi historicamente mais uma questão sul-americana do que latino-americana. Para o México e os países centro-americanos e caribenhos, a ênfase sempre recaiu sobre a noção de soberania, devido ao histórico de anexações territoriais, de intervenções militares e de políticas de desestabilização. ${ }^{14}$ Por sua vez, os países sul-americanos

${ }^{14}$ Entre 1845 e 1846, os Estados Unidos anexaram 1,3 milhões de quilômetros quadrados do território mexicano, uma área que correspondia aproximadamente à metade daquele país. Após a guerra contra a Espanha, em 1898, anexaram Porto Rico e intervieram em Cuba, para ficar apenas no continente americano. A partir do Corolário Roosevelt à Doutrina Monroe, de 1904, uma grande variedade de situações passou a definir a natureza e a duração da intervenção: presença de tropas para defender a propriedade e os bens de norte-americanos; "protetorado" financeiro com ocupações das alfândegas; apoio ou repulsa a 
tiveram relativamente maior margem para implementar políticas externa, comercial e cultural mais autônomas em relação aos Estados Unidos. Não por acaso, parte considerável da literatura sobre autonomia foi realizada na América do Sul, mais especificamente no Cone Sul.

No final dos anos 1970, Hélio Jaguaribe (1979) fez importante contribuição ao debate sobre autonomia. Para o autor, é possível passar de uma situação de dependência para outra de autonomia, desde que duas condições estruturais sejam alcançadas: "viabilidade nacional" e "permissividade internacional". A primeira faz menção à existência de recursos humanos e sociais adequados à capacidade de inserção internacional e ao grau de coesão sociocultural interna; a segunda, de caráter geopolítico, está relacionada à capacidade de neutralização de ameaças externas e depende de recursos econômicos e militares, além de alianças com outros países. $\mathrm{O}$ autor identifica também dois fatores dinâmicos fundamentais para a existência da autonomia na periferia: autonomia tecnológica e empresarial, capaz de garantir algum grau de desenvolvimento endógeno, e relações favoráveis ou não antagônicas com o centro.

A corrente de pensamento à qual pertenceram Hélio Jaguaribe e Juan Carlos Puig ficou conhecida como "realismo da perifeira”. Influenciados pelo pensamento da CEPAL, esses autores concebiam o sistema internacional como sendo assimétrico e atravessado por relações de poder. A autonomia era vista como uma condição, e não uma conquista estável e permanente. As estratégias para alcançar essa meta incluíam melhoria das técnicas de negociação, alianças regionais e integração política e econômica. Nesse sentido, o "realismo da periferia" logrou construir uma teo-

políticos para favorecer interesses econômicos ou estratégicos estadunidenses; e ocupação direta e administração de países "instáveis" (Feres Jr., 2005; Moura, 1990). Durante a Guerra Fria, as intervenções se multiplicaram. Neste século, tornaram-se emblemáticas as ingerências na política venezuelana, hondurenha e paraguaia. 
ria normativa orientada para a ação política. No caso do Brasil, as ideias sobre autonomia passaram a ser relacionadas ao conceito de desenvolvimento, e ambos foram integrados à política externa do país (Giacalone, 2012; Jaguaribe, 1979; Russel e Tokatlian, 2003; Vigevani e Cepaluni, 2011).

Nas décadas de 1980 e 1990, a crise da dívida e a ascensão de governos de centro-direita fizeram com que as políticas econômicas secundassem as reformas de mercado do Consenso de Washington. No mesmo sentido, as políticas externas, apesar de variações relevantes, alinharam-se com a orientação dos Estados Unidos. O caso mais emblemático foi a Argentina de Carlos Menem, que adotou as propostas de caráter utilitário de Carlos Escudé, o qual recomendava uma política exterior que eliminasse confrontações políticas com as grandes potências. Segundo essa estratégia, gestos de autonomia deveriam ser abandonados, caso prejudicassem os objetivos econômicos e contribuíssem para o isolamento do país. No Brasil, substituiu-se uma política externa autônoma, que apoiava o modelo de desenvolvimento industrializante, por uma política exterior menos altiva, a qual adotava "atitudes positivas" em relação aos novos temas e aos regimes internacionais. No âmbito regional, as políticas externas de Argentina e Brasil traduziram-se em um Mercosul liberal ou "fenício", conforme expressão crítica de Gerardo Caetano, e em uma proposta de integração heteronômica (Fonseca Jr., 2004; Giacalone, 2012; Guimarães, 2008; Russel e Tokatlian, 2003).

No início do século XXI, a vitória eleitoral dos partidos progressistas levou à adoção de políticas econômicas mais intervencionistas, de políticas sociais distributivistas e de políticas externas autônomas. Em relação à integração regional, a ideia de "América do Sul”, como constructo e como projeto, passou a se sobrepor à de "hemisfério". ${ }^{15}$ Ao mesmo tempo, resgatou-se o conceito de auto-

${ }^{15}$ Segundo Leslie Bethell (2010), no início do século XIX, o presidente Thomas Jefferson e o senador Henry Clay foram os primeiros a conceber a ideia de “hemisfério ocidental”. Posteriormente, os Estados Unidos promoveriam o 
nomia, que assumiu matizes variados: desde a oposição moderada à heteronomia anterior até o antagonismo aberto à tradicional disposição geopolítica das Américas. A adoção de um modelo de "confrontação autonômica" ou de "confrontação antagônica" dependeu de fatores internos, como, por exemplo, a orientação ideológica dos governos (Guimarães, 2008).

Os modelos alternativos de inserção econômica e geopolítica no sistema internacional devem ser entendidos como recursos que são apropriados por atores sociais e políticos nacionais e traduzidos em programas de governo que refletem interesses e ideologias de coalizões específicas, conforme características próprias de cada país. A convergência liberal do passado recente cedeu lugar à adoção de estratégias diversas por parte dos governos sul-americanos. Na última década, enquanto alguns países buscaram ampliar sua integração à economia internacional e implementaram políticas liberais, como Chile, Colômbia e Peru, outras nações, a exemplo de Argentina, Brasil e Venezuela, passaram a adotar um "regionalismo pós-liberal” (Motta Veiga e Rios, 2011; Sorj e Fausto, 2011).

Há, portanto, uma clara segmentação das estratégias de inserção internacional vigentes na América do Sul, reforçada pela politização das agendas econômicas domésticas e externas. $\mathrm{O}$ deslocamento para a esquerda do eixo de poder político em diversos países da região faz ressurgir certo nacionalismo econômico e acentua a oposição entre liberais e revisionistas (Motta Veiga e Rios, 2011). De acordo com César Guimarães (2008, p. 244),

conceito de pan-americanismo, com sua ênfase em uma história e geografia compartilhadas, além dos ideais republicanos. Ademais, fariam uma tentativa de institucionalizar a ideia de "hemisfério ocidental", as Américas, como região separada da Europa, em uma série de conferências envolvendo os Estados do continente americano. 
Os nacionalismos, contudo, ainda que tendam a uma integração sul-americana mais ambiciosa e autônoma, constituem um dos aspectos mais polêmicos dos novos modelos, exatamente porque o nacionalismo econômico readquiriu, no contexto da globalização, o viés de esquerda que remete aos processos de descolonização de meados do século XX. A oposição que suscita tem bases similares, internas e externas, àquelas que a Guerra Fria tão claramente evidenciou, aí se incluindo certa pobreza conceitual, presente, por exemplo, no populismo como noção elástica e vazia.

Diante desse quadro de crescente heterogeneidade, que envolve desde governos liberais a outros com diferentes projetos autonômicos, faz-se necessário um minimo denominador comum institucional, de caráter político e econômico, capaz de envolver, sem distinção, todos os países da região (Guimarães, 2008). Nesse contexto, destaca-se a proposta da Unasul, cujo caráter multidimensional aponta para uma concepção ampliada de integração, que envolve simultaneamente os aspectos político, social, econômico e cultural. Ademais, abrange dimensões tão diversas quanto a territorialidade e a consolidação de uma infraestrutura que garanta a integração física do continente. A preponderância da natureza política da Unasul reflete-se em um projeto de inserção soberana da América do Sul como forma de superar seu tradicional estatuto de periferia do capitalismo e, simultaneamente, concebe as metas de um desenvolvimento nacional voltado para a superação das históricas desigualdades sociais de cada país (Sarti, 2011).

Apesar das diferenças contextuais, é possível traçar um paralelo entre a reação dos Estados Unidos aos processos de autonomia sul-americanos e a oposição daquele país à criação da CEPAL, em 1947. Na época, os norte-americanos argumentaram que um órgão regional da ONU seria desnecessário, pois já existia a União Pan-Americana, antecessora da Organização dos Estados Americanos 
(OEA). Ademais, acreditavam que a criação da nova instituição duplicaria o Conselho Econômico e Social da OEA e significaria um desperdício de recursos. Diante do impasse, o governo Truman (1945-53) absteve-se da votação que criou a CEPAL e somente concordou com o seu surgimento como uma experiência de três anos, após os quais seria tomada uma posição definitiva. Por ocasião da quarta sessão da CEPAL, realizada na Cidade do México, em 1951, o governo norte-americano retomou a manobra para encerrar os trabalhos da comissão, propondo sua fusão com o Conselho Econômico e Social da OEA. No entanto, o plano teve de ser abandonado diante da oposição latino-americana a essa manobra. Naquele momento, cumpre destacar o papel desempenhado pela delegação brasileira, que frustrou os planos estadunidenses ao comunicar que o Brasil se opunha a qualquer resolução que minasse a futura independência da CEPAL (Dosman, 2011; Furtado, 2013).

Historicamente, a política externa brasileira articulou o conceito de autonomia com o de desenvolvimento econômico. Entre 1930 e 1980, operou-se uma ligação estreita e virtuosa entre os objetivos do modelo de substituição de importações e o objetivo de construir uma política externa autônoma. Apesar de esse vínculo ter se modificado profundamente durante a hegemonia neoliberal dos anos 1990, as administraçóes do PT lograram reincorporar à política externa do país metas de desenvolvimento (Lima e Hirst, 2009). Nos anos 2000, assistiu-se ao ressurgimento do desenvolvimentismo, agora com o nome de novo desenvolvimentismo. O neodesenvolvimentismo procura combinar elementos de trajetórias distintas, recuperando o papel protagonista do Estado e incorporando aspectos das reformas de mercado. O resultado é uma síntese institucional que se expressa em uma modalidade de desenvolvimento retomando a tradição estruturalista, adaptada e redefinida aos novos tempos (Bresser-Pereira, 2013; Diniz e Boschi, 2013). 
No atual modelo de desenvolvimento, o Banco Nacional de Desenvolvimento Econômico e Social (BNDES) e o Itamaraty constituem segmentos de excelência dentro do aparato estatal brasileiro, responsáveis pela condução de dois importantes pilares da agenda desenvolvimentista do governo: os planos interno e externo. $\mathrm{Na}$ articulação entre esses dois níveis, deve-se ressaltar o papel do BNDES na promoção de oportunidades para o capitalismo doméstico e, em particular, nas iniciativas tomadas para fortalecer a competitividade da economia brasileira (Diniz e Boschi, 2013). Desde 2002, a diretoria do BNDES aprovou diretrizes para financiar os investimentos de empresas brasileiras no exterior, com o objetivo de orientar a criação de uma linha capaz de estimular a inserção e o fortalecimento dessas firmas no mercado internacional, além de promover o crescimento das exportações. Na mesma época, uma alteração no estatuto do Banco autorizou o apoio a empreendimentos no exterior, desde que resultassem no estímulo à exportação de produtos domésticos. Ademais, o suporte a investimentos diretos no exterior deveria beneficiar exclusivamente empresas de capital nacional, além de representar uma oportunidade para que fossem efetuados investimentos estratégicos em projetos de integração regional (Além e Cavalcanti, 2005).

Em sua análise sobre o imperialismo, Nikolai Bukharin (1984, p. 73) observa que "todo capitalismo nacional revela uma tendência constante a estender-se, a alargar seu poderio, a sair dos limites das fronteiras nacionais. Isso decorre da própria essência da estrutura capitalista da sociedade". Com isso, não se pretende afirmar que o Brasil é um país imperialista, mas destacar a tendência de expansão inerente a qualquer economia nacional capitalista relativamente avançada. No entanto, diferentemente dos países europeus, o Brasil não exporta seus instrumentos nacionais de violência. Além disso, embora seu peso se sobressaia no continente, o Brasil não pratica políticas de hegemonia, mas prioriza soluções diplomáticas (Fonseca Jr., 2004; Lima e Hirst, 2009). 
O surgimento da Unasul coincidiu com o aumento da presença de empresas brasileiras nos países vizinhos, gerando conflitos entre as dimensões política e econômica do projeto de integração. Deve-se ressaltar, entretanto, que a internacionalização das empresas brasileiras é um processo anterior à constituição da Unasul. Nos últimos anos, tal presença tem ocorrido sobretudo por meio de aquisições de empresas locais, raramente por associação ou investimento em novas instalações. Nesse movimento expansivo, observa-se uma concentração das grandes empresas nacionais nos setores de recursos naturais, commodities semiprocessadas e serviços, especialmente nas áreas financeira e de engenharia. Portanto, à medida que aumentam os investimentos brasileiros diretos na região - tendência aparentemente "natural" -, o risco de tensões políticas tende a crescer (Schneider, 2009; Sorj e Fausto, 2011).

O movimento de extrapolação da economia brasileira tem sido impulsionado pela dinâmica global de valorização das commodities e respaldado pelo apoio do Estado nacional, particularmente por meio de financiamentos do BNDES. A valorização das commodities impulsiona, simultaneamente, a internacionalização de empresas em setores intensivos em recursos naturais e pressiona outras empresas industriais a procurar ambientes com custos reduzidos. Para a indústria brasileira, a valorização cambial associada ao baixo dinamismo das economias dos Estados Unidos e da União Europeia (UE) aumenta a importância da América do Sul como possível destino de suas exportações (Motta Veiga e Rios, 2011; Sorj e Fausto, 2011).

Diante da expansão das transnacionais brasileiras, os países vizinhos veem a si mesmos enfrentando uma poderosa aliança entre as empresas e o Estado brasileiro: tanto ou mais assimétrica que as economias é a capacidade estatal do país em apoiar sua atividade empresarial. Além disso, está em curso o aprofundamento de uma especialização produtiva desigual na América do Sul, com a transferência da propriedade de ativos econômicos 
dos demais países para segmentos da burguesia brasileira. Nesse sentido, a estratégia do Brasil tende a reproduzir no plano regional uma lógica econômica de tipo Norte-Sul, que prevalece no âmbito global: por um lado, o país se transforma em fornecedor privilegiado de produtos manufaturados para a região; por outro, converte-se no principal comprador de produtos primários (Luce, 2008; Solanas, 2011).

A reação ao perigo de uma dependência econômica percebida como excessiva em relação ao Brasil se converte em temor ao "subimperialismo brasileiro". Na realidade, a divisão regional do trabalho e o contexto assimétrico de integração remetem à ideia de subimperialismo, elaborada por Ruy Mauro Marini, na década de 1960. Para Marini (2012), o impulso da economia brasileira em direção ao exterior seria uma tentativa de compensar o insuficiente mercado interno do país. Tal argumento, no entanto, se encontra em contradição com a realidade de hoje, pois a recente internacionalização das empresas brasileiras coincide com a criação de um mercado de consumo de massas. ${ }^{16} \mathrm{~A}$ ideia de subimperialismo parece igualmente inválida, pois o prefixo aponta para a inserção do caso brasileiro no marco da hegemonia exercida pelo imperialismo estadunidense, o que não é verdade. Todavia, continua válida a tese defendida por Marini de que o movimento de expansão tinha por objetivo reduzir os custos de produção. Recentemente, a Federação das Indústrias do Estado de São Paulo (FIESP) defendeu a transferência de algumas atividades produtivas para o Paraguai, em função dos custos mais baixos de mão de obra e energia. Já a Confederação Nacional da Indústria (CNI) levou 180 empresários para visitar o país vizinho, com a expectativa de utilizar o

\footnotetext{
${ }^{16}$ Segundo André Singer (2012), no período de 2003 a 2005, a proporção de pessoas abaixo da linha da miséria caiu 19,18\%; já entre 2003 e 2009, cerca de 30 milhões de pessoas ascenderam à classe $\mathrm{C}$. Além das políticas de transferência de renda, o governo Lula promoveu a gradual elevação do salário mínimo, que teve uma valorização real de $50 \%$ entre 2002 e 2010.
} 
baixo custo paraguaio para enfrentar a concorrência chinesa (Marini, 2012; Neumann, 2014; Pedroso, 2013).

Para entender o conflito entre as dimensões política e econômica do projeto de integração centrado na Unasul, faz-se necessária uma breve análise da IIRSA, que será aprofundada no capítulo 4 . A IIRSA visa à integração física do subcontinente, com destaque para os setores de energia, transporte e infraestrutura. Refletindo a atmosfera de inserção subordinada e de hegemonia neoliberal, os projetos da iniciativa estavam voltados à atração de investimentos externos para a criação e a expansão de corredores de exportação de produtos regionais de baixo valor agregado.

Com o governo Lula, passou-se a criticar o caráter de mercado da IIRSA e seu controle pelas grandes agências financeiras multilaterais. O Ministério das Relações Exteriores (MRE) procurou recuperar sua capacidade de influenciar os rumos do processo de integração física da América do Sul. Ademais, o BNDES tornou-se um importante financiador dos principais projetos no âmbito da IIRSA. Segundo Luciano Wexell Severo (2011), esses financiamentos não apenas contribuem para o desenvolvimento da infraestrutura dos países da região, como também vêm estimulando a expansão internacional de empresas brasileiras, sobretudo nos setores de construção civil, siderúrgico, petrolífero, petroquímico, alimentício, máquinas e aviação civil.

O protagonismo brasileiro nos marcos da IIRSA é interpretado politicamente como expressão do expansionismo econômico, sobretudo diante das condicionalidades impostas pelo BNDES. Os esforços para avançar na área de cooperação política, como é o caso da Unasul, tendem a ser muito mais difíceis do que a simples liberalização recíproca dos fluxos comerciais, pois há muitas dificuldades em operacionalizar tanto as políticas de redução de assimetrias quanto aquelas voltadas para o objetivo de complementação produtiva.

Em suma, esta seção procurou mostrar, de maneira resumida, a tensão entre a dimensão política e econômica do novo regionalismo 
sul-americano centrado na Unasul. A ascensão de partidos progressistas resultou na adoção de políticas externas e econômicas que resgataram o conceito de autonomia. Apesar das diferenças entre as coalizões políticas de cada país, a Unasul converteu-se num espaço de articulação regional comum que tende a projetar geopoliticamente a América do Sul. No entanto, esse processo de caráter político, apoiado decisivamente pela política externa do Brasil, coincidiu com a expansão das empresas brasileiras na região, causando tensões entre a lógica diplomática e a lógica empresarial.

\subsection{Síntese do capítulo}

Este capítulo analisou o papel dos fatores sistêmicos e domésticos na formulação e na implementação da política externa, partindo da premissa de que uma análise abrangente da política internacional requer uma articulação entre as dimensões externa e interna. Os Estados nacionais, conquanto não sejam os únicos atores num sistema cada vez mais complexo, continuam extremamente relevantes. Todavia, as decisões de política externa são tomadas por líderes e coalizões de atores coletivos que dirigem o aparato estatal. As ideias e os valores dos grupos domésticos tornam-se fundamentais para a compreensão do desenho de determinada política exterior, concebida, aqui, como uma política pública. Ademais, cabe à comunidade política interna realizar a mediação dos impactos das forças sistêmicas, pois a forma de inserção internacional depende, em cada caso, das relações entre classes, coalizões de poder, partidos políticos, burocracias e lideranças no interior de cada Estado.

Ao longo do capítulo, destacou-se a estreita relação entre Estado e capitalismo, poder e dinheiro, além dos fatores que tornaram possível o sucesso desse entrelaçamento no Ocidente. $\mathrm{O}$ desenvolvimento do capitalismo na Europa foi responsável pela constituição simultânea de um sistema internacional, baseado em Estados nacionais, e de um sistema transnacional integrado 
a um mercado global em formação, nos marcos do qual ocorreu a generalização do novo modo de produção. No século XIX, a política imperialista fundiu a acumulação de capital e a violência estatal em um processo de expansão contínuo. A hegemonia britânica combinou de modo virtuoso o colonialismo e o livre comércio, logrando articular duas lógicas de poder distintas, por vezes contraditórias, mas que se entrelaçam de formas complexas: a lógica territorial e a lógica capitalista. Além disso, o Estado mostrou-se a entidade política mais apta para orquestrar essas dinâmicas, mantendo as duas lógicas sempre interligadas, ainda que nem sempre convergentes.

No século XX, os Estados Unidos criaram uma forma específica de imperialismo, baseado numa retórica universalista que procurava disfarçar suas ambições territoriais. Para entender a hegemonia norte-americana, é preciso analisar a sociedade de consumo de massas e o modelo de produção que surgiram originalmente nos Estados Unidos. A política mundial contemporânea, assim, é resultado de uma hegemonia específica, exercida tanto pelo governo estadunidense quanto por uma vasta gama de instituições, cujas normas se baseiam na sociedade de mercado gestada naquele país.

A atual globalização deve ser compreendida como um projeto hegemônico vinculado ao cálculo geopolítico e aos interesses econômicos dos Estados Unidos. A forma moderna assumida pelo capitalismo foi desenvolvida, então, a partir das modificaçóes ocorridas na economia norte-americana. Nesse sentido, a grande corporação estadunidense constituiu-se no embrião nacional do posterior desdobramento de transação do grande capital. Da mesma forma, o regime econômico internacional do pós-Segunda Guerra, o embedded liberalism, foi uma tentativa de generalizar o modo de regulação keynesiano e o sistema de produção fordista que tinham se firmado nos Estados Unidos do New Deal. 
Conforme analisado, as instituições de Bretton Woods, o Welfare State e o fordismo nunca foram totalmente aplicados aos países em desenvolvimento. Com a CEPAL, criou-se um pensamento original que contribuiu para uma análise do desenvolvimento desigual do capitalismo como sistema econômico mundial organizado hierarquicamente. A nova organização, portanto, produziu uma teoria própria do desenvolvimento, com base nas condições reais e na história das nações latino-americanas. Utilizando conceitos inovadores, a CEPAL denunciou as assimetrias inerentes ao sistema internacional, que tendiam a perpetuar o subdesenvolvimento dos países periféricos. Dessa forma, a teoria cepalina propôs um modelo de industrialização por substituição de importações, que deveria ser coordenado pelo Estado, como forma de superar a pobreza e a brecha entre o centro e a periferia.

A crise do fordismo e o surgimento do regime de acumulação flexível levaram ao fim do consenso keynesiano. Com isso, o ressurgimento das ideias neoliberais resultou da erosão do equilíbrio até então existente entre Estado e sociedade, liberando os processos impessoais da concorrência capitalista que haviam sido regulados pelo Estado de bem-estar social. Com o colapso de Bretton Woods e o fortalecimento da alta finança, os Estados Unidos promoveram políticas de abertura comercial e impuseram a liberalização financeira em todo o mundo. Por consequência, a reformulação das instituições econômicas internacionais e a imposição de ajustes estruturais diminuíram a margem de manobra dos países periféricos.

No novo milênio, o acontecimento geopolítico e geoeconômico mais significativo foi a ascensão da China como o centro mais dinâmico dos processos de acumulação de capital. Apesar de os Estados Unidos continuarem sendo uma potência econômica e militar, o surgimento do BRICS pode contribuir para a consolidação de uma ordem mundial mais híbrida e tornar as instituições internacionais menos liberais. No âmbito regional, a vitória de partidos progressistas levou os países sul-americanos a adotarem políticas externas 
mais autônomas. Na última década, a política externa brasileira empenhou-se na criação de um novo regionalismo. Nesse sentido, a criação da Unasul como foro de articulação política contribui para a projeção geopolítica da América do Sul, que pode se converter em um novo polo mundial, tornando a região menos dependente dos Estados Unidos. Por fim, observou-se que o advento da Unasul coincidiu com o avanço da expansão das grandes empresas brasileiras na região, gerando tensões entre as dimensões política e econômica da diplomacia brasileira. 